\title{
Interpretations of the Fall Narrative
}

\subsection{Introduction}

The Fall narrative is presumed to be the foundation of woman's inferior status and tainted character in Jewish and Christian societies, because of her supposed instigation of the primeval source of sin and death. In this chapter I propose to dispute this mindset and to demonstrate, through a critical and meticulous line-by-line scrutiny of the relevant biblical text, that an interpretation unbiased by preconceptions of gender characteristics does not even hint at such a conclusion. Instead, the account clearly places the primary human responsibility upon the man, as can be seen from the quite neutral portrayal of the woman's actions, and the much more judicial and punitive approach taken by God with Adam and the serpent in the incident's aftermath. The majority of scholarly studies on the status of women concentrate on Christian, rabbinic, and Qumran literature, and critical analysis of the primary biblical source has often been lacking or absent altogether. For instance, John Collins ${ }^{1}$ analyses the relevant verses of Gen 3:1-24 from a primarily theological viewpoint, ignoring textual critical analysis. For example, he writes that God gave them [my italics] "strict instructions regarding one tree"2 (at Gen 2:16-17), an incorrect statement that may not be significant theologically but is obviously critical in judging the woman's guilt to be minor, since Eve was not yet created when God gave His instructions to Adam, and to him alone. This fact is crucial in establishing the primary guilt. In fact, the author of Jubilees, having a preconceived notion of the woman's guilt and being aware of the significance of this and many other biblical passages that contradict his theory, simply changed them, adapting them to his prejudiced opinion. These sometimes blatant changes indicate that a more impartial reading of the biblical text affirms the contrary, and thus supports my proposed interpretation.

This chapter will consider other aspects of the presumed biblical attitude toward women and discuss relevant scholarly studies on these topics. For instance, one does not encounter derogatory comments about women in Scripture, undermining the assumption that such prejudice is scriptural in origin. As far as can be determined from the scarce Qumran writings on

1 John J. Collins, Genesis 1-4, 166-178.

2 Ibid., 169.

(C) PAUL HEGER, 2014 | DOI 10.1163/9789004277113_004 
these issues, it would seem that Qumran scholars took a more straightforward approach to scriptural interpretation than the later rabbis, and also had a more neutral view of women. Finally, given the ample rabbinic writings from a variety of genres on the interpretation of the Fall and its ethical and halakhic ramifications, it will be possible to develop a more elaborate perspective on rabbinic attitudes toward men and women and their underlying philosophy and theology. The midrashic technique certainly brought more layers to interpretation but also, as I will argue, reflects an underlying pragmatism: insisting, for instance, that women "cover up" in public might implicitly stigmatize them as temptresses, but may also have seemed more effective in preserving family stability in the social conditions of the time than attempting to police the unruly male libido.

\subsection{The Biblical Text: Problems and Interpretations}

\subsubsection{Close Textual Analysis of Gen 3:1-14}

The story of the Fall begins: "Now the serpent was more crafty ערום of the wild animals the LORD God had made" (Gen 3:1). Scripture's emphasis on the fact that the serpent is the shrewdest of all animals, an apparently superfluous detail, proves to be a decisive factor in determining which of the characters involved is mostly to blame for the sin and the consequent calamity. Indeed, beginning the narrative with this detail indicates the author's sympathetic attitude towards the woman, displaying an understanding for her falling into the trap of this wily character, who skillfully frames the discussion to attain his goal. ${ }^{4}$ Indeed, since the serpent is probably aware ${ }^{5}$ that God's

3 Genesis = [Be-reshit $]$; LXX translates this word as "cunning," KJV "subtil" and JPS "the shrewdest."

4 Hartley, Genesis, 65 writes that "its [the serpent's] skeptical approach drew the woman into discussion and opened her to considering that God might have acted out of self-serving motives." But nevertheless, "the woman wisely sought to correct the serpent," stating that God permitted them to eat from any tree, except one. Hamilton, The Book of Genesis, 189 proffers another perspective of the serpent's astute approach in achieving his goal of making man fail. By exaggerating God's prohibition, the serpent attempted "to create in the woman's mind the impression that God is spiteful, mean, obsessively jealous, and self-protecting," as he indeed implies in Gen 3:5. Blenkinsopp, Creation, 73 writes: "We can readily understand that, confronted by such a formidable interlocutor, the woman had little chance of winning the verbal duel."

5 Hamilton, ibid., writes: "The serpent would have learned about God's commands from the humans." 
command not to eat from the tree has been given to Adam, not to the woman, ${ }^{6}$ he chooses to speak to her, framing his approach as a question and raising doubt in her mind about the authenticity of Adam's admonition to her about the tree. ${ }^{7}$ The serpent plausibly knows that his question is deceptive, ${ }^{8}$ since he must have seen that they ate from all the other trees of the Garden, yet he asks Eve: "Did God really say, 'You must not eat from any tree in the garden?' " (Gen 3:1 $)^{9}$ The woman begins her reply by negating his assumption, but in her naiveté she volunteers information on an issue he has not asked about, saying: "We may eat fruit from the trees in the garden, but God said: 'You must not eat fruit from the tree that is in the middle of the garden, and you must not touch it, or you will die.' "10 We know that God did not prohibit touching the tree,

6 Sarna, Genesis/בראשית, JPS, writes: "She is therefore the more vulnerable of the two, the more susceptible to the serpent's insidious verbal manipulation."

Abot R. Nat. Recension a, Chapter 1 unveils the serpent's well-devised plan to entangle Adam and bring him to failure. Its interpretation is formulated according to a biased conception of the woman's inferiority, arguing that the serpent attempted to use the weak, ignorant woman to achieve his objective; see Tertullian, De Cultu Feminarum, The Fathers of the Church (Dokkum:J. Kaminga, 1934). Adam's weakness is evident, since Adam ate the forbidden fruit without any effort at temptation from Eve. Hence, the man seems inferior to the woman; he exercises no personal consideration or judgement and is easily led astray. Bernard M. Levinson, The Right Chorale: Studies in Biblical Law and Interpretation (Tübingen: Mohr Siebeck, 2008) 43 describes the serpent's cunning reversal of the syntax of the original divine dictum.

The Hebrew expression אף כי כis unusual, and its translation and interpretation are vague. It appears only once in the entire Pentateuch and must be interpreted differently in the context of the other occurrences in Scripture. The KJV interprets it: "Yea, hath God said" (in interrogative mode), suggesting Eve's suspicion regarding the truth of what Adam told her. Tg. Onq. adds the term בקושטא ארי "but is it true" that God said, confirming the suspicion that the serpent took advantage of Eve's not having heard God's command to arouse her suspicion. The traditional commentator Rashi interpret it as: "perhaps" God has told you. The LXx here translated the expression in an uncommon copula $\tau i$ o 0 เ interpreted by Albert Pietersma and Benjamin G. Wright, in A New English Translation of the Septuagint (New York: Oxford University Press, 2007) as "why is it," whereas it should have rather been translated from the philological standpoint as "what is it." In fact, the same expression in 1 Sam 14:30 is translated by the LXX $\alpha \lambda \lambda^{\prime}$ " o $\tau \iota$ and by the NIV and KJV as "how much more," demonstrating the oddity of this expression in our verse.

10 This is the NIV interpretation, which does not consider correctly the meaning of the biblical term פן, expressing a possibility. The KJV interprets it "lest you die," following the LXX, which expresses a more potential possibility, but not as definite as when God said to Adam "you will surely die" (Gen 2:17). The term פן in Scripture definitely expresses possibility or contingency (see Gen 26:7). Onkelos and Pseudo Jonathan indeed translate the

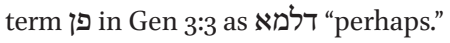


and although God said to Adam that he will surely die on the day he eats the fruit (Gen 2:17), the woman says פן תמתון "you may die," without any indication when that may occur. The author of the narrative conceals from us, however, what Adam said to the woman. It is plausible to assume that Adam indeed told her that God prohibited even touching the forbidden tree, an incorrect statement that modified the divine command, as Abot R. Nat. Recension a, Chapter 1 alleges. ${ }^{11}$ Such a possibility is more reasonable than supposing the woman invented this detail, changing God's command in such a radical manner. ${ }^{12}$

As Gen 3:4-6 recounts, the serpent next convinces the woman that she and Adam will not die; eating the fruit will open their eyes, giving them the faculty to discern good and evil. In consequence of these reasonably convincing claims and facts (as the midrash argues; see note 11), we read in v. 6: "When the woman saw that the fruit of the tree was good for food and pleasing to the eye, and also desirable for gaining wisdom, she took some and ate it. ${ }^{13}$ She also gave some to her husband, who was with her, and he ate it." The author emphasizes again that the woman's action is logical, given the superlative praise of the tree and its fruit and her wonderful experience after having eaten the fruit without

11 See the contents of this midrash on p. 87, arguing that because of Adam's inexact transmission of God's command, the serpent could convince the woman that Adam lied to her. In another version of this midrash, Adam's allegedly increasing the severity of God's prohibitions is criticized, since the serpent could more easily convince Eve of the falsity of Adam's transmission to her of God's command. We read in Gen. R. parsha 19: "When he [the serpent] saw her passing at the tree, he pushed her to touch the tree; he said to her: behold you did not die by touching it, equally you will not die by eating it."

12 Gerhard von Rad, Genesis: A Commentary (Revised Edition, translated from the German by John H. Marks, Philadelphia: Westminster Press 1972) alleges that the woman changed the command, "going a bit too far in her zeal;" hence, without evil intentions. In Eve and Adam: Jewish, Christian, and Muslim Readings on Genesis and Gender (ed. Kristen E. Kvam, Linda S. Schearing, and Valarie H. Ziegler; Bloomington, IN: Indiana University Press, 1999), 33, it is postulated that presuming the woman changed the divine command received from Adam, she did so because of a confusion between the tree of knowledge and the tree of life. God prohibits Adam to eat from "the tree of knowledge" (Gen 2:17), but Eve mentions "the tree that is in the middle of the garden" (Gen 3:3).

13 Hamilton, The Book of Genesis, 190 writes that the virtue of the tree to make one wise was the most attractive feature for Eve, since it would give her something she did not "presently possess." Humans frequently crave what they do not have. Elyse Goldstein, The Women's Torah Commentary: New Insights from Women Rabbis on the 54 Weekly Torah Portions (Woodstock, vT: Jewish Lights Publishing, 2000), at 50 writes: "The Torah, surprisingly, explains Eve's inner motives, quite out of character for the Torah, which rarely divulges such personal reflections. Only after such contemplation does Eve actively reach for the fruit, it is not an impulsive act." 
any adverse effects. ${ }^{14}$ Only after that, as a thoughtful and dedicated wife, does she offer her husband the fruit. ${ }^{15}$ In contrast to the elaborate presentation of the serpent's scheming, the author portrays the woman's action as straightforward, without the slightest hint that she is tempting Adam into eating the fruit.

Cassuto notes that Adam does not ask any questions: it suffices for him that the woman gave him the fruit to eat, since "it is the way of the world for the man to be easily swayed by the woman."16 One discerns here a rabbinic influence in the presumed power of a woman to seduce a man; the biblical text, however, does not suggest this. On the other hand, Sarna, in his JPS commentary to Gen 3:6, observes that "the woman is not a temptress." He argues further that the serpent's conversation with the woman is in the presence of Adam as well, since the serpent uses the plural mode in his speech. This is supported by the biblical phrase (Gen 3:6b) ותתן גם לאישה עמה "and she gave also to her man [who was] with her)" - the man is with her when she gives him the fruit to eat, ${ }^{17}$ hence he must be well aware of the serpent's cunning arguments and nevertheless decides of his own will to transgress the divine command. ${ }^{18}$ The author underscores the woman's abstention from any attempt at inducing Adam to eat, by emphasizing through the narrative's portrayal the different

14 In effect, the text indicates that the woman saw the fruit's property of bestowing wisdom before having eaten it, which is highly questionable. Hence, it demonstrates the biblical author's consistent aim to minimize the woman's guilt. The traditional commentators Rashi and Ibn Ezra, aware of the dilemma, interpreted the term ותרא "she saw" not in a concrete manner, but rather to mean that she realized the serpent's discourse made sense, and she believed him.

15 Here too, the rabbis, in Abot R. Nat. Recension b, Chapter 1, eager to defend their affirmations of the woman's guilt and corrupt character, indicate her depraved and egoistic character, alleging, among other things, that immediately after having eaten the fruit she saw the angel of death approaching her. She surmised that she was going to die and that God would create another woman for Adam. To avoid this, she decided to feed Adam the forbidden fruit (Gen 3:6b), so that either both would die or both would survive. In contrast, another midrash says: "Having eaten the fruit of the tree and perceiving that nothing harmful occurred to her, she contemplated that all Adam had commanded her was false."

16 Cassuto, Commentary on Genesis, 148.

17 Hebrew does not require a verb for the formation of a sentence; the context implies the auxiliary verb "to be." Sydney Greidanus, Preaching Christ from Genesis (Grand Rapids, Mich.: Eerdmans, 2007) writes that Adam, "who had received the commandment directly from God, should have stopped her."

18 See n. 55 in Chapter 1, p. 27, regarding Milton's Paradise Lost on this topic. It is amazing to observe the broad range of exegesis, comparing this interpretation to that of Abot. R. Nat. cited above in n. 15 . 
circumstances that shape her decision compared to his, and through the presentation of their defence. In fact, the woman says in her defence that the serpent deceived her, whereas Adam just says, "The woman gave me the fruit," corroborating that the woman did not make any special effort to convince him. Note also the biblical author's portrayal of the woman's prudent thinking, even though she has not heard the divine prohibition. In contrast, Adam does not reflect on God's explicit prohibition, but makes a hasty decision to eat the fruit.

In summary, the biblical text demonstrates a recurrent emphasis on the mitigating circumstances of the woman's actions, which continues a fortiori as the narrative progresses, shifting the blame on to Adam. We read in vv. 8-9 that both Adam and Eve heard וישמעו the Lord's coming into the Garden, and both hid (although the MT states that both ויתחבא האדם ואשתו "Adam and his wife hid," it uses the masculine ויתחבא "he hid");19 Adam too in his reply to God states in the singular ואחבא "so I hid." But the Lord called only upon the man "Where are you," emphasizing again Adam's primary role, being the only one summoned by God. ${ }^{20}$ The language thus demonstrates Adam's primary responsibility in the sinful episode, as is also evident from the subsequent divine dialogue and accusation, explicitly directed to him alone (3:10-11). (In contrast, in God's blessing [Gen 1:28-30], the granting of authority to humans over all other creatures and the allotment of food is addressed equally, in the plural, to man and woman.) God addresses only Adam, and after listening to his explanation for his hiding (vv. 9-10), asks him alone, in a judicial manner, who told him to be naked and whether he transgressed the divine command given to him not to eat the fruit from the particular tree (v. 11). The woman is neither accused of disobedience, nor interrogated in the same manner as Adam. As an impartial judge, God would have asked her whether she indeed performed a criminal act by transgressing his command, but he posed instead a somewhat odd question, "What is this you have done?" (v. 13), instead of the expected "Why have you done this?" Such a question would have followed logically from Adam's reply in v. 12 that the woman gave him the fruit. ${ }^{21}$ Further, the question

19 The Lxx cites the term $x p \dot{u} \pi \tau \omega$ "hide/cover" in the plural, since Greek grammar, like Modern Hebrew, does not permit the use of a verb in the singular for a deed performed by more than one subject. Biblical Hebrew, however, permits the use of the singular in cases when one subject is the primary actor or agent and the other is secondary, as in our case, since from now on God converses solely with the man in vv. 9-12.

20 The LXx text reads: “Adam, where are you?" It seems entirely plausible that the translator added Adam's name at the beginning of the question to emphasize his personal guilt and responsibility for the misdeed.

21 Indeed, the LXx interpreted this question using the conjunction $\tau$ í "why," as did the Vulgate, using the conjunction quare "why." 
does not contain any description of her supposed deed, as one would expect in a judicial interrogation.

Although God knows that the woman ate the fruit before Adam and then gave it to him, God interrogates Adam first because he is the one whom God prohibited from eating the fruit, indicating that God considers him the principal guilty party. From the different style and content of the interrogations of Adam and the woman, we observe God's dissimilar attitudes towards their responsibilities for the mischief: God's question to the woman does not have the character of an accusation. This conclusion is corroborated by the peculiar way the author of Jubilees changed significant details of the biblical narrative of the Fall in order to adapt it to his preconception of the woman's primary guilt. Jubilees ignores, for example, the entire episode of God's conversation with Adam and the woman and their responses, and similarly omits key passages in other places in the Fall narrative, as I shall demonstrate in section 2.2.3.

\subsubsection{Gen 3:14-24: Distinct Retributions for Adam and Eve}

After the pleas of Adam and the woman, each attempting to pass the blame to somebody else, the narrative reaches its climax: God's judgement, the delivery of the verdict, and the pronouncement of the punishment. From the structure and literary style of vv. 14-19, which comprise the last phase of the narrative, we observe that God does not accept Adam's plea of innocence on the basis of blaming the woman, as implied by his words in v. 12: "The man said, "The woman you put here with me she gave me [some fruit] from the tree, and I ate it.' " God perceives Adam and the serpent as the principal offenders; he convicts them and imposes on them the most severe retributions, as we observe from the succeeding text. ${ }^{22} \mathrm{He}$ does not interrogate the serpent, conjecturally because he knows that the serpent has no excuse. ${ }^{23}$ In fact, none of the involved parties has an explanation for their deeds; Adam and the woman merely attempt to pass the blame onto a third party, who, as they contend,

22 Compare Lacks, Women and Judaism, who writes at 15: "Lord God, however, in his eternal and supernal wisdom, doesn't accept Adam's story and sends both of them out." She seems to feel that God perceived both Adam and Eve as equally guilty and respectively punished, overlooking that vv. 23-24 records the expulsion from the Garden in the masculine singular. Emphasizing Adam's origin from the ground cannot refer to Eve, created from his rib. Eve's accompanying Adam out of the Garden does not demonstrate her guilt or conviction; she must follow her husband, being one flesh and bone.

23 Westermann, Genesis 1-11, 255 writes that J discerns between the people and the serpent "pointing out the basic meaning of human responsibility, namely, the people have to answer for what they do." 
incited them, and the serpent cannot even make that plea, being the "primary mover" of the incident.

In every judgement, the judge, after listening to the evidence and pleadings of the defendants, first delivers his verdict, declaring them innocent or guilty, before proceeding to pass sentence. Likewise, God proclaims both the כי עשית משת לקו

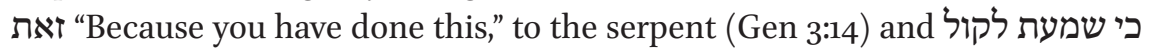
"Because you listened to your wife and ate," to Adam (Gen 3:17). In contrast, there is no such conviction of guilt in God's words to the woman, which are transmitted indirectly by the narrator: "To the woman he said, 'I will greatly increase your pains in childbearing; with pain you will give birth to children. Your desire will be for your husband, and he will rule over you'" (v. 16). ${ }^{24}$ Like God's question to the woman, which does not have the character of an accusation or interrogation, his indirect pronouncement to her does

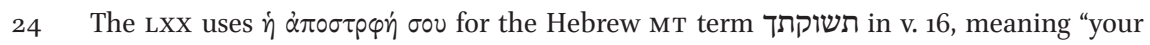
turning back," according to Wevers' Notes on Genesis translation. This translation would be appropriate for the Hebrew term תשובתך, but Wevers thinks that "it is unnecessary to presuppose" such a reading. However, Charles, Apocrypha and Pseudepigrapha also translates in Jub. 3:25 the biblical parallel of Gen 3:16 as: "thy return shall be unto thy husband," a fact which hints that there may have been some biblical Mss with the term תשובתך. Avraham Kahane, The Apocryphal Books (Tel Aviv: Massada, 1959 [Hebrew]) conjectures that the Lxx had a Hebrew Vorlage with the term תשובתך, and comments that this term appears in the Ethiopian version, which served as Charles' Vorlage. Tg. Neof. interprets it similarly: ולוות בעליך יהוי מתביך: "and to your husband you will return." This term, which does not allude to the woman's sexual desire as an aspect of her character as Wevers assumes, would thus delineate a more favourable portrayal of the woman. Her turning back to her husband would be associated with her virtuous character to turn back to her husband for having more children, despite her pain in giving birth. However, Stephen Andrews, "What's the Matter with Eve? The Woman and her Sentence in Ancient Judaism," in Divine Creation in Ancient, Medieval, and Early Modern Thought; Essays Presented to the Rev'd Dr Robert D. Crouse (ed. Michael Treschow et al.; Leiden: Brill, 2007), 1-22, at 7 states: "it is hard to see how $\alpha \pi \circ \sigma \tau$ то $\eta^{\prime}$ could mean 'desire,' " suggesting that the LXX translator "had a text with תשובתך or, in a kind of ancient malapropism, he was of the opinion that תשובה תשוקת equaled." By extension, one who comes back from his/ her own will demonstrates that he/she wishes or desires it, which explains the translator's pattern of thought. See n. 100 on p. 82 on that topic. It seems that Andrews cannot accept the simple meaning of the text, indicating that God implanted the sexual desire in humans, and therefore it cannot be wicked and in need of suppression, since what God has done is always good. 
not bear the character of a guilty verdict, nor of a consequential punishment. ${ }^{25}$ There is no accusation, nor even mention of the fact that the woman ate the forbidden fruit, presumably because she did not hear God's command transmitted to Adam. The inescapable conclusion is that God's approach to the woman is entirely different from those pursued with the other two parties to the incident. The content and style of the narrative also portray the woman's participation in the event as minimal in comparison to that of the other two participants. The divine punishment of the serpent, involving perpetual hostility and deadly conflict between humans and serpents, mentions the woman's descendants, not the man's, since the serpent tried to corrupt the woman but had no contact with the man. It does not, however, indicate a punishment of the woman for her guilt, nor for that matter a punishment of her offspring.

The style of the biblical text of God's communication with the woman at Gen 3:16 is different enough to raise the plausibility it is a later interjection, not organically related to the antecedent and succeeding verses. ${ }^{26}$ Its literary style in the MT, starting with אל האשה אמר "to the woman he said," in contrast to the use of the conjunction ולאדם "and to Adam" in v. 17, hints likewise at this possibility. ${ }^{27}$ The aetiological purpose of such an interjection would be the justification of the actual circumstances in Israel at the time of the narrative's final redaction. ${ }^{28}$ It is obvious that both the creation model in Gen 2 and the Fall narratives in Gen 3 are of partially aetiological character, justifying the woman's lesser status and lack of independence in society and in her relationship with her husband.

As already hinted above, I postulate that the divine communication to the woman in v. 16 should be perceived as neither a punishment ${ }^{29}$ nor an

25 Blenkinsopp, Creation, at 56 writes: "The verdict on the man and the woman is not a punishment distinct from the expulsion into a harsher world, but simply a description of what life outside the garden will entail."

26 Schmidt, Die Schöpfungsgeschichte, 215 states: "Already the formal differences... make it clear that this passage has another source than the surrounding castigations."

27 Both the Samaritan and the Lxx versions added the stylistically appropriate conjunction ואל האשה "and to the woman," and the LXX added xai to connect it to the foregoing curse of the serpent, but this conjunction is absent in the мт.

28 Frymer-Kensky, In the Wake of the Goddesses, 128 writes: "The superior position of husbands was never justified or explained in the Bible by claims to innate male superiority," and "the hierarchical division between men and women was yet another social institution that the biblical Israel shared with her neighbours and did not think to question."

29 Bal, "Sexuality," 36 states: "The content of Jahweh's words to her is not even presented as the consequence of what she has done, let alone a punishment." 
indication of her inferior status because of her involvement in the Fall episode. According to the Creation narrative of Gen 1, to assign inferior status to the woman would have been against God's intention of complete equality between the two genders. On the other hand, the Creation narrative of Gen 2, proclaiming the creation of the woman from the man's rib and his declaration before God that "This is now bone of my bones and flesh of my flesh; she shall be called 'woman,' for she was taken out of man," creates the woman's inequality. It establishes the woman's dependence on the man, her craving for reunion with her primeval source and her lack of an independent individual legal status. The consequences of this narrative, not of the Fall, show up in God's communication to the woman in the peculiar verse 3:16: man's dominion over woman is not a punishment for her part in the Fall narrative, but the consequence of her creation from man. It would have been highly unjust for the man, the primary sinner in God's eyes, to be rewarded by dominion over the woman, the minor transgressor. Cassuto, who comprehends Adam as the main sinner, ${ }^{30}$ nevertheless perceives the woman's "punishment" of subservience to the man as conforming with the rabbinic maxim of מדה כנגד מדה "measure for measure," presumed to be the divine standard; she made Adam do her will and her punishment is to do his will henceforth. However, the application of this rule seems neither just nor appropriate in this case. To grant the main sinner in the mutual transgression domination over his wife as a reward would be tantamount to a reversal of justice. Furthermore, the "punishment" of the woman to desire her husband and be subservient to him has no textual association at all with her assumed sin, unlike the evident linkage of the crime and the punishment of the serpent, and a life of sorrow for Adam as a punishment for the transgression of the divine command. The exclusive use of the term אישך in the Pentateuch only in the Fall narrative and at the test of the Unfaithful Wife (Num 5) instead of the term also indicate the equality between man and woman. Whereas the term אשל בי מאיש לקחה generated, as explained בי בעל as

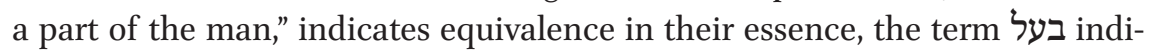
cates possession, as in בעל הבית in Exod 22:7 and in Exod 21:3 and 22, in which the woman's destiny is determined by her husband: the wife of the Israelite slave is freed when her husband is, and the husband decides the amount of the fine to be paid for the punch suffered by his wife. ${ }^{31}$

$30 \quad$ Cassuto, Commentary on Genesis, 138 calls this narrative "Adam's sin."

31 I am indebted to Professor Herb Basser for drawing my attention to the oddity of the term אישך. - (20) 
Barry Bandstra, who has made a meticulous analysis of every phrase of Gen 1-11 from grammatical and syntactical perspectives, ${ }^{32}$ states that the clause "Your desire will be for your husband, and he will rule over you" in the second part of v. 16 does not appear to be a curse so much as a statement of fact. I tend to have the same perception regarding the first part of v. 16. Carol Meyers interprets it as related to sexual intercourse; despite the woman's reluctance to enter into the risks of pregnancy and birth, "the male's will within the realm of sexuality is to be imposed on the will of the female... yet because she experiences desire and yearning for man, such male control would not be experienced as oppressive;" hence the indirect type of penalty. ${ }^{33}$ Further, the relationship of עצמי ובשרי "Bone of my bone and flesh of my flesh" between man and woman (Gen 2:23) portrays a particular form of ameliorated domination that cannot be perceived as a punishment. When the tribes of Israel asked David to be their ruler, they expressed their motive in choosing him and the relationship they expected between them thus: הננו עצמך ובשרך אנחנו "We are your flesh and blood" (2 Sam 5:2). Such an affiliation cannot be perceived as a punishment; likewise the relationship between man and woman. ${ }^{34}$

The first part of God's communication to the woman, even if perceived as a punishment, does not compare in severity to the punishments inflicted on Adam and the serpent, and would, even in this case, serve as evidence for the minor nature of the woman's sin. The pain of giving birth is in practice a natural event experienced by many kinds of living beings, and occurs intermittently a limited number of times in a woman's life. Further, the pain's intensity is not

32 Barry Bandstra, Genesis 1-11: A Handbook on the Hebrew Text (Waco, Tx: Baylor University Press, 2008), 206.

33 Carol Meyers, Rediscovering Eve: Ancient Israelite Women in Context (Oxford: Oxford University Press, 1988), 116-117. Remarkably, the traditional commentator Ramban similarly associates the woman's desire for the man with the procreation process: "I find it appropriate that God punished her [Eve] to crave excessively for her husband, and thus she will not be intimidated by the pain of pregnancy and birth." Though he does not mention it, a midrash in Gen. Rab. parsha 20 interprets Gen 3:16b as follows: "When the woman sits on her travailing chair, she proclaims: 'I will never have sexual relations with my husband,' and The Holy be He blessed says to her: 'You will hark back to your desire, you will again desire for your husband." Rashi similarly relates the first part of the verse to sexual intercourse, but in a different way than Meyers or Ramban, stating: "[you will desire] sexual intercourse, but despite it you are not daring to ask for it boldly, but he will rule over you [intending] everything (the initiative) will come from him, and not from you." There is no hint of a punishment or dominance in Rashi's view. I am indebted to Professor Harry Fox leBeit Yoreh for drawing my attention to the relevance of 2 Sam to our topic. 
universally equal; in natural or primitive societies it seems to be negligible, but even in our modern societies, we observe that the compensating great joy of giving birth to children, which is exclusive to women, generally far exceeds the pain associated with it. Women often face enormous hardships and hurdles in order to become pregnant. Stephen Andrews interprets the term עצב not as "pain" but as a "psychological or emotional discomfort;" thus he translates the verse: "I will greatly increase your distress and [or 'in'] your pregnancies." ${ }^{35}$ By comparison, man's punishment, consisting of a continuous and lifelong uphill battle for sustenance, entails more overall hardship. Scripture emphasizes explicitly the ceaseless calamity of the man's punishment: "through painful toil you will eat of it all the days of your life" (Gen 3:17), and reiterates the point in Gen 3:19: "By the sweat of your brow you will eat your food until you return to the ground." 36 It is remarkable that the rabbis, who, as we shall see, shift the blame of the Fall onto the woman, are nonetheless aware that Adam's punishment is more severe than hers. For instance, we read in Gen. Rab. 97:3:37 "Said Rabbi Jose son of Halafta, 'Earning one's sustenance is twice as burdensome than [the pain of] giving birth; at the birth is written בעצב [and] at earning one's sustenance is written בעצבון (the longer term is presumed to demonstrate its greater severity).' "38

A traditional commentator, Torah Temimah, conjectures that Rabbi Jose was baffled by the assumption that the woman, the lesser offender, would be punished more severely than the man. Therefore, he attempted to demonstrate that the man's punishment was indeed more severe. We observe that even a

35 Andrews, "What's the Matter with Eve?" 3.

36 See Hamilton, The Book of Genesis, 203.

37 The same dictum appears in b. Pesah. 118a in the name of Rabbi Johanan, one of the first Amoraim.

38 It is odd that the Tanna deduced this from a longer term used at the man's punishment, a flimsy piece of evidence, instead of the difference between man's continuous plight versus the woman's temporary pain, softened by love. Perhaps he preferred to deduce his conclusion from the two different biblical terms, since according to tradition, acknowledged by the rabbis, one gains knowledge even of natural physiological rules from the interpretation of the Torah, not from observation. Carol L. Meyers, "Gender Roles and Genesis 3:16 Revisited," A Feminist Companion to Genesis (ed. Athalya Brenner; Sheffield: Sheffield Academic Press, 1993) 118-141, at 130-131 argues that the עצבון Gen 3 "clearly refers to the physical labor... but is nowhere associated with the description of childbirth." She argues that in Ps 127:2 the same term "links long hours of work with the procurement of the 'bread of labors." As regards the woman, however, the use of the term intensifies the female contribution to society, "as both the woman's contributive labor and her pregnancies are quantitatively increased." 
traditional commentator, and plausibly also the Tanna Rabbi Jose, educated in light of the ingrained rabbinic opinion about the primary guilt of the woman in the Fall, had some doubt as to the integrity of this viewpoint; indeed, one may observe such doubt also in some dicta of the ancient rabbis. The punitive and humiliating style of God's verdict to Adam is remarkable, and emphasizes Adam's great sin and corresponding punishment. From his elevated position in domination of all creatures in Gen 1:28-30, he is degraded to the status of animals to eat the plants of the field, ${ }^{39}$ and his quintessentially inferior origin from dust is stressed.

A further critical analysis of God's verdict and punishment of Adam in vv. 17-19 supports my overall thesis about the biblical attitude to the relationship between man and woman and the assignment of guilt resulting from the Fall narrative. To begin with, the opening phrase of God's verdict on Adam, "Because you listened to your wife," seems extremely odd. It gives the impression that Adam's main misdeed was to listen to his wife, rather than to eat the prohibited fruit, an accusation that is mentioned only subsequently as if it were a secondary infraction. This reading is supported by the use of the conjunction ו ותאכל ind," seemingly pointing to a wrongdoing additional to the first, his listening to his wife. At any rate, it raises the question of what is wrong with listening to one's wife; if it is not wrong, its citation is superfluous.

According to my postulate, this pronouncement relates to the woman's dependence on man as a result of her creation from his rib. Adam has reversed the logic of God's creation of the woman from man's rib and her consequential dependence on him as one of his parts, who ought to obey him as one of his limbs would. Having done the opposite in listening to his wife, he cannot excuse his guilt on account of listening to her when, in her capacity as a companion created for him by God, she should rather be listening to him. ${ }^{40}$ Thus,

39 Whereas in Gen 1:29 Adam is also given "every tree that has fruit with seed in it," now, in Gen 3:18, he will eat only "the plants of the field," like the beasts and the birds in Gen 1:30. A midrash in Abot R. Nat. Recension a, Chapter 1 records: "[When Adam heard that] he said 'Master of the World, I and my animal will eat from the same manger?' "

Hartley, Genesis, 70 writes: “The man's responsibilities were to obey God and to encourage the woman in obeying God." He continues: "This he failed on two accounts." Andrews, "What's the Matter with Eve?" 10 reflects similarly to my thesis: "Perhaps the wife was regarded as an extension of the husband's person and therefore subject to his control in the same way he would exercise self-control in the avoidance of sin," but reaches the opposite conclusion regarding Adam's or Eve's main culpability. He argues that "Eve's offering of the forbidden fruit to Adam, would indicate that the woman's desire was in some fashion an unhealthy one." The woman "has certainly the power of intimate suggestion, and she places before her husband an enticement to sin," although the biblical text 
this apparent oddity supports my thesis that the woman's subordination to her husband is the consequence of her creation from his bone and flesh, and the purpose of her creation to function as man's helper, rather than a punishment for her involvement in the Fall.

Two additional elements indicate the crucial difference between God's punishment of Adam and His communication to the woman. ${ }^{41}$ The term "curse" appears at the serpent's and Adam's verdicts, ${ }^{42}$ whereas no expression of malediction is mentioned in the divine dialogue with the woman. And last but not least is the fact that God communicates for the first time to man about his limited temporal existence in the world; that is, his imminent death. Hence, according to an unbiased reading of the narrative, the man's sin is the cause of death coming to humanity within the framework of his punishment. It is remarkable how this obvious fact has been overturned and the coming of death to humans has been attributed to the sin of the woman. Further, according to rabbinic law an accomplice to a criminal act is not liable to punishment, as they would be in modern law; only the perpetrator of the act is liable. We read in b. Qidd. 42b the maxim: "There is no agent for a forbidden deed, because we say: Do you obey the command of the teacher [God] or of the student [a human]?" From this legal viewpoint, Eve should not be punished for giving the prohibited fruit to Adam, and she is not charged with having eaten it, probably since God did not explicitly prohibit her eating the fruit. Only Adam disobeyed God's command; his excuse that his action was instigated by the woman is not valid, and therefore he alone is guilty of the transgression. In fact, at the end of the episode, with the application of the ultimate punishment, his ephemeral life and his expulsion from the Garden and degradation, we read in Gen 3:23: "So the LORD God sent (NIV banished) him from the Garden of Eden to work the ground from which he had been taken." Only Adam, the primary

portrays the woman's action as straightforward, without any hint of an effort to tempt or convince Adam to eat the fruit. Ignoring his own admission that Adam "was at liberty not to heed [her enticement]," Andrews concludes that "the exhortation for the husband to rule his wife occurs in the ethical context of whether or not he will follow her into sin." Andrews seems to me to approach the interpretation of the narrative with many preconceptions regarding the woman's intrinsically evil disposition. Thomas W. Franxman. Genesis and the "Jewish antiquities" of Flavius Josephus (Rome: Biblical Institute Press, 1979), at 61 likewise states that God accused Adam of having subdued himself to his wife, a woman.

41 Westermann, Genesis 1-11, 263 writes: “[Adam's] sentence clearly carries the most weight; it is the most detailed and the crime is mentioned yet again."

42 Although Adam is not cursed, the earth is cursed on his account, specifically to make his life miserable. 
sinner, is mentioned, and his expulsion is reiterated in v. 24 in a derogatory manner: ויגרש את האדם "he drove Adam out." These and the previously identified differences between God's approaches to Adam and to the woman point to the peculiarity of God's words to the woman from a great range of viewpoints, and lend support to the hypothesis that v. 16 is an extraneous text.

\subsubsection{Jubilees' Intentional Changes to the Biblical Text}

The author of Jubilees, however, had a different preconceived notion of the woman's guilt, and being aware that the existing biblical text contradicted his theory, changed the relevant biblical text at critical instances to adapt it to his own viewpoint. For example, he totally ignored God's command to Adam not to eat the fruit of knowledge of good and evil in Gen 2:17: it does not appear at all in his parallel narrative of the biblical account of the Creation and Fall. The first mention of such a command appears in Jub. 3:17, in the serpent's speech to the woman, in the plural mode, and is acknowledged by the woman in v. 18. We observe here a premeditated contrivance to alter the biblical text's characterization of the woman's involvement as minor. Clearly, as we have seen, God's command to Adam, in Eve's absence, not to eat the prohibited fruit imputes to him the main responsibility for obeying it, and the accusation of transgressing it; it attenuates the woman's guilt in the violation and its consequences. Thus, Jubilees' omission and adjustments of important biblically recorded events confirms the author's awareness that the original biblical text conflicted with his viewpoint about the woman's guilt. ${ }^{43}$

The literary style and structure of God's interrogation of Adam and Eve, their pleading, God's pronouncement of the verdict and punishment of the involved parties, and the banishment from the Garden (as related in Gen 3:11-24) all indicate, as I have shown, the woman's lesser involvement in the accusation and guilt in the biblical narrative. These factors are at variance with the conventional interpretation, which perceives the woman as principally culpable for the calamities befalling humanity and her gender's character as consequently tainted. Therefore, the author of Jubilees skipped the entire

43 We encounter an identical misrepresentation of the woman's guilt in the Lxx. In contrast to the MT, which emphasizes in Gen 2:17 that God's prohibition to eat from the tree of the knowledge of good and evil was uttered to Adam, before Eve's creation, the LXx translates all the verbs in that verse in the plural, thus implicitly accusing her of willfully transgressing the divine prohibition, plausibly as a result of the Hellenistic influence that portrays women in a bad light from many aspects. See Judith Romney Wegner, "Philo's Portrayal of Women," in "Women Like This": New Perspectives on Jewish Women in the Greco-Roman World (ed. Amy-Jill Levine, Atlanta, GA: Scholars Press, 1991) 41-66. 
episode of God's interrogation of and conversation with Adam and Eve recorded in Gen 3:8-13, and moved straight from the making of the fig leaves by Adam and his wife, as recorded in Gen 3:7, to God's cursing the serpent, recorded in Gen 3:14. God's exclusive dialogue with Adam with respect to his transgression of the divine command addressed to him, and the distinctive style of Adam's interrogation versus God's neutral questioning of Eve, were omitted by Jubilees' author for the same motive, namely to minimize Adam's guilt as implied by the biblical text. Van Ruiten searches for other reasons besides this motive, which seems obvious, especially if we consider all the changes in Jubilees together and search for a common denominator. ${ }^{44}$

Likewise, the author of Jubilees made subtle changes to the biblical text of God's communication to the woman in Gen 3:16. He avoided putting in God's mouth an accusation or conviction of the woman, something which He did not utter, as recorded in Scripture, ${ }^{45}$ and therefore he expressed his preconceived opinion of the woman's guilt in an indirect style, asserting: "And He was wroth with the woman, because she hearkened to the voice of the serpent, and did eat; and He said unto her: 'I will greatly multiply thy sorrow...'" (Jub. 3:24). There is nowhere any mention in the biblical text of God being angry with the woman, or any accusation based on her listening to the serpent's inducement. The author of Jubilees justifies the woman's punishment on the basis that she ate the prohibited fruit, a connection that does not appear in Scripture. Furthermore, the conjunction בי "because," pointing to a motive for the alleged "punishment" as the consequence of wrongdoing, appears in Scripture only at the delivery of the divine verdicts on the serpent and on Adam, but not at His statement to the woman..$^{46}$ One is also led to ask the following questions: how did the biblical narrator know that God was angry, and what was the reason for his anger?

The author of Jubilees even went a step farther in his attempt to minimize the serpent's and Adam's guilt while maximizing that of the woman. He started, as in Scripture, with God's curse of the serpent in vv. Gen 14-15, but drastically

44 J.T.A.G.M. van Ruiten, Primeval History Interpreted: The Rewriting of Genesis 1-11 in the Book of Jubilees (Brill: Leiden, 200o), 97 speculates that one reason, among others, for Jubilees' omission of the interrogation is that the biblical account of God's questioning of Adam and the woman shows Him as "innocent and uninformed," since an omniscient God would have known what had happened; thus, the omission avoided the presentation of God's diminished portrayal.

45 He may have been concerned about the specific admonishment of Deut 18:20: "But a prophet who presumes to speak in my name anything I have not commanded... [is to be put to death]."

46 See Trible, God and the Rhetoric of Sexuality, 126. 
shortened it, omitting even the content of the curse and simply recording: "And God cursed the serpent, and was wroth with it forever." Thus, he minimized the cursing of the serpent, whereas he recorded exactly and in its entirety the biblical text of Gen 3:16 relating to God's pronouncement regarding the woman. He also added the conjunction "and" in the serpent's curse and in the statement to the woman, absent in the MT, thus unifying the text relating to all three involved personages to underline their common guilt. As we have seen, the communication to the woman in Scripture stands apart in all its aspects, in its essence and its literary style, from those relating to the serpent and the man, revealing a marked distinction between them. However, at God's verdict on Adam the Jubilees author writes in 3:25: "And to Adam also he said, 'Because thou hast hearkened unto the voice of thy wife.'” By the addition of the adverb "also" (translation R.H. Charles), absent in Scripture, he made Adam's guilt and punishment secondary to that of the woman, an ancillary to her primary guilt. As with his distorted redaction of the serpent's curse, he also shortened the biblical text of Adam's verdict and punishment, amalgamating the three relevant biblical verses Gen 3:17-19 into a single verse, Jub. 3:25. ${ }^{47}$

As we have seen, ${ }^{48}$ in the Creation narrative (Gen 1:27-28) God created both man and woman in His image and equalized their rank and task in the universe and their right to sustenance. The creation of both man and woman accomplishes the completion of the divine creation of the universe, and God's satisfaction is superlative, "very good" (Gen 1:31) rather than just "good," as He judges all other accomplishments of the Creation. ${ }^{49}$ Thus, the text of vv. $27-28$ points clearly to the woman's equality in all the above aspects.

The author of Jubilees, however, apparently determined to deny the woman's equality and her significance in the world, omitted in its entirety the blessing of multiple offspring at the Creation narrative, bestowed by God upon man and woman alike (despite leaving this same blessing at God's covenant with Noah in Jub. 6:5). He also changed the biblical text explicitly granting dominion

47 We read there: "And to Adam also he said, 'Because thou hast hearkened unto the voice of thy wife, and hast eaten of the tree of which I commanded thee that thou shouldst not eat thereof, cursed be the ground for thy sake: thorns and thistles shall it bring forth to thee, and thou shalt eat thy bread in the sweat of thy face, till thou returnest to the earth from whence thou wast taken; for earth thou art, and unto earth shalt thou return."

48 See Chapter 1, p. 36, n. 87 .

49 The NIV and the KJV both translate this as "it was good," interpreting it in the past. There is no verb in the original Hebrew, and the Lxx does not use a verb either in its Greek translation, but one is required in English. I believe the phrase should logically be perceived as being in the continuing present. 
over all other creations to both man and woman into: "He gave him dominion" (Jub. 2:14; my italics).

Similarly, the Jubilees author ignored the text of Gen 1:29, in which food is granted equally to man and woman, writing instead at Jub. 3:16: "And he tilled (the garden), and was naked and knew it not, and was not ashamed, and he protected the garden from the birds and beasts and cattle, and gathered its fruit and ate, and put aside the residue for himself and for his wife." He thus revoked the woman's divinely endowed share of the fruit of the garden, granting it entirely to Adam; therefore, Adam ate first, and then put aside the remainder for his wife.

However, the most significant deviation the Jubilees author made from the biblical text to deny woman's equality is the total omission of Gen 1:27 describing God's creation of man and woman in his image..$^{50}$ It is as though he would rather omit explicitly declaring the creation of man in God's image than acknowledge the equality of man and woman. In this case again, van Ruiten overlooks Jubilees' deliberate changes in order to create a particular interpretation.

At the end of the Garden/Fall episode, Gen 3:21 records that God made garments of skin for Adam and his wife and clothed them, in plural mode. However, at the expulsion of man from the Garden, the consequence of man's transgression of the divine command, Scripture records solely Adam's expulsion, and the start of his punishment "to till the ground from which he was taken," as appears in Gen 3:19 in Adam's verdict. The description of these events that again seem to attribute the sin of transgressing God's command and its punishment to Adam, not to Eve, did not fit the Jubilees author's perception of the Garden/Fall episode. He therefore changed the biblical text, omitting the restatement in v. 23 of Adam's punishment in v. 19 to return to the ground from which he was taken, the motive for the expulsion, and jumped from the phrase "and God clothed them" to continue "and sent them forth from the Garden," in plural. Thus, he equalized Adam and Eve with regard to the transgression and expulsion. These constant changes of the biblical text by the Jubilees author, using as one might say "every trick of the trade" and skipping over elements that did not fit or contradicted his preconceived view of the woman's guilt, indicate the significance he attached to systematically adapting the biblical narrative to the predominant conception in his period of the woman's guilt for the Fall and its harsh consequences. It demonstrates, on the other hand, that an unbiased reading of the original biblical text does not indicate this conclusion, but rather the opposite. 


\subsubsection{Scriptural Attitudes towards Women}

The interpretation of the biblical Fall narrative discussed above is supported by the fact that there are no derogatory imputations about women in the Bible ${ }^{51}$ and no direct hints of seductive tendencies on their part. ${ }^{52}$ The Bible cares for women's rights and interests within the framework of their legally dependent status, a consequence of their mode of creation from man..$^{53}$ We encounter in

51 Frymer-Kensky, In the Wake of the Goddesses, 118 states: "The pre-exilic biblical texts present a coherent and consistent picture of the nature of women." At 127 she draws attention to the contrast between the Bible's description of women and Greek mythology, replete with tales of women who kill their husbands, fathers, or sons.

Ibid., 141 states: "The Bible never considers eros a tool of women, as something against which men should guard." I have some doubts about this sweeping statement, in particular regarding the narrative of the relationship between Abigail and David. At 130 and (primarily) 132-134, Frymer-Kensky portrays Abigail in superlative terms, praising her wisdom and rhetorical astuteness, but the narrator emphasizes Abigail's beauty and her intelligence as early as his introduction of the principal characters, plausibly for the sake of justifying or even glorifying David, who married her. Her plea with David does not demonstrate any consideration of loyalty to her husband, such as asking for his safety, and her marriage with David, immediately after Nabal's strange death, cannot be overlooked in judging her character; it rather demonstrates her selfishness and seductive ability. We may also consider Esther's seductive capability to drastically and instantaneously change Xerxes' entrenched esteem of Haman, whom he had elevated to a position higher than all other nobles (in modern parlance, his prime minister), so that he delivered him to the gallows.

53 Eckart Otto, "False Weights in the Scale of Biblical Justice? Different Views of Women from Patriarchal Hierarchy to Religious Equality in the Book of Deuteronomy," in Gender and Law in the Hebrew Bible and the Ancient Near East (ed. Bernard M. Levinson et al.; Sheffield: Sheffield Academic Press, 1998), 128-46, at 140 asserts that the deuteronomic family laws were concerned with brotherly and sisterly solidarity and the protection of the status and rights of women, alleging different attitudes towards women in Exodus than in Deuteronomy. I agree with Otto that some of these rules express care for the wellbeing of women, but argue that they do not change their dependent legal status; according to Deut 22:29 the father, not the daughter, receives the compensation money for her virginity lost by the act of a rapist, according to the rabbis, and by the act of a seducer, according to Qumran's understanding. The rules regarding the Slandered Woman (Deut 22:13-21) likewise do not represent the character of a totally indiscriminate approach to the man and the woman. In fact this rule is discriminatory; if the man lies, he does not suffer the same harsh consequences as the female liar. He is merely punished by the Elders, at their discretion (b. Ket. 46a specifies that it refers to lashes) and a fine, whereas the woman is executed by stoning, the most brutal capital punishment; he should have been executed by the same procedure as the malicious witness, which he indeed is (Deut 19:19). Moreover, the biblical text of Deut 22:21, convicting the woman to death by stoning, does not specify whether it refers to an accusation of adultery after her betrothal to the man or 
Scripture numerous admonitions for the defence and assistance of women in general and against discrimination towards widows in particular. Deut 24:17 forbids taking a pledge for ensuring a loan from a widow. Deut 14:29 compares widows to Levites regarding the obligation of ensuring their subsistence. It is remarkable that Deut 27:19 includes among the eleven curses to be proclaimed at Mount Ebal a curse upon "the man who withholds justice from the alien, the fatherless or the widow." Exod 21:7-10 establishes preferred rules for the release or marriage of a maidservant at coming of age, ${ }^{54}$ and is concerned with her well-being and legal rights if her owner/husband marries another wife in addition to her. Num 27 records the divine decision ensuring the right of inheritance by Zelophehad's daughters of his property. Exod 22:15 compels a man to marry the girl he seduced. Deut 21:14 protects even the rights of the Captive Woman; if her captor does not like her, he cannot sell her but must let her go free. Isaiah and Jeremiah call passionately for the rights of widows. Although Scripture indicates the motive of the levirate law "to carry on the name of the dead brother (Deut 25:6)," we cannot exclude the likelihood that the care for the widow's subsistence, left without children to support her, was also a factor considered in the institution of this rule. ${ }^{55}$

We also encounter many positive pronouncements regarding women. Genesis records Isaac's great love of Rebekah (Gen 24:67) and Jacob's love of Rachel (Gen 29:18, 20). Gen 16:2 records that Abraham agreed to Sarai's suggestion, and Gen 21:12 narrates God's mandate to Abraham: "Listen to whatever Sarah tells you." The Patriarchs and their lives are the model of Israelite virtuous conduct. We read a remarkable rule in Deut 24:5: "If a man has recently married, he must not be sent to war or have any other duty laid on him. For one year he is to be free to stay at home and bring happiness to the wife he has married." We observe the explicit justification that the bridegroom is absolved from the military duty to "bring happiness to the wife," not to himself as in the cognate decree in Deut 20. The significance of this assertion is further

beforehand: how can one be sure that her betrayal occurred after her betrothal? The rabbis interpreted this rule as relating to a proven accusation of adultery after her betrothal. On the other hand, Alexander Rofé, Deuteronomy: Issues and Interpretation (London: T \& T Clark, 2002), 173-74 referring to this issue, as it appears in Scripture, asserts that "we must conclude that whoever formulated the opening verses and the rest of the first section (Deut 22:15-19) did not write the second (vv. 20-21)."

54 Some scholars are at variance with my interpretation of this biblical rule. See the discussion in Chapter 3, pp. 114-118.

55 Rofé, Deuteronomy, 140 dismisses the biblically indicated motive for the levirate law, stating: "Deut 25:5-10 was a provision that was concerned with the legal and economic protection of a woman living in an especially vulnerable position." 
enhanced by the comparison with the other motives for absolving men from the military service at war in Deut 20:5-7. There, the justification for the man who has become "pledged to a woman and not married her" is identical to the man who has built a new house or planted a new vineyard. They may die in battle, and someone else would enjoy the new house or vineyard or marry the girl. Since the man has not yet married the girl, she will not suffer if he dies; however, if he has already married her, Scripture relieves him from military duty for her exclusive benefit.

There is no hint in Scripture of the danger of woman's sexuality, as alleged by some scholars. ${ }^{56}$ The test of the Unfaithful Wife in Num 5 does not hint at woman's seducing faculty or other immoral traits. This test, embarrassing though it may be in modern eyes, applies only when a feeling of jealousy overcomes the husband, probably because he has observed something that led him to such a supposition or because there is a conspicuous suspicion of her infidelity, as we read in Num 5:12-13. ${ }^{57}$ In either case a solution must be devised in order to safeguard the stability of the marriage and of the family, and Scripture establishes an innocuous albeit perhaps humiliating procedure. ${ }^{58}$ We have to

$5^{6}$ See for example, Wassen's statement in Women, 207: "Following the biblical tradition in general, this law code (CD) sees female sexuality as a dangerous force." Women's seductive ability portrayed in the cases of a few specific women (see above n. $5^{2}$ ) are a long way from Wassen's comprehensive and radical allegation. I do not perceive such an assumption or conception either in Scripture or in Qumran writings.

57 Verse 14 may be construed as hinting that the test may be carried out without explicit evidence, solely as a result of the husband's jealousy. Scholars have debated the peculiarity of the text, which may suggest an amalgamation of two or three texts. Michael A. Fishbane, "Accusation of Adultery: A Study of Law and Scribal Practice in Numbers 5:11-31," HUCA 45 (1974), 25-45 and Tikva Frymer-Kensky, "The Strange Case of the Suspected Sotah (Numbers V 11-31)," VT 34 (1984), 11-26 reject this possibility and posit understanding the repetitions as a typological biblical style, used in many instances. Timothy R. Ashley, The Book of Numbers (Grand Rapids, MI: Eerdmans, 1993) states: "A single reading of the passage from most modern translations suffices to show the literary difficulties," and FrymerKensky admits at 18 that the differences may indicate a later expansion of the original text. At any rate, the primary text relates explicitly to a well-founded suspicion.

$5^{8}$ The rabbis discern between the circumstances of solely the man's jealousy, and a more serious suspicion. According to $\mathrm{m}$. Sotah $1: 1$ and 2 the husband must warn his wife before two witnesses not to speak to or meet with the man he suspects of having some relationship with her. If she nevertheless speaks with the man, she is still permitted to live with her husband, and does not need to pass the ordeal. (This rule may be compared to the Code of Hammurabi §131: "If her husband accuses his own wife [of adultery], although she has not been seized lying with another male, she shall swear [to her innocence by] an oath by the god, and return to her house.") Only if after his admonition before witnesses 
compare the apparently disagreeable procedure of the biblical text with the Code of Hammurabi §132: "If a man's wife should have a finger pointed against her in accusation involving another male, although she has not been seized lying with another male," a suspicion of lesser degree than that portrayed in Num 5, "she shall submit to the divine River Ordeal." ${ }^{9}$ The suspected transgressor was thrown into the deep river with the belief that the innocent would float and the guilty would drown, constituting a real danger of death to the innocent and guilty alike, whereas the biblical rule uses solely a psychological device inducing the woman to confess, if she had indeed committed adultery. Further, if the woman was guilty of adultery, but without legally valid evidence, she could admit it and be divorced without the right of any financial compensation, but also without corporal punishment, since Scripture requires two witnesses for any conviction. We read in $m$. Sotah 1:5: "If she said that she is polluted [she slept with another man] she loses her ketubah [financial compensation at a divorce] and is divorced." 60 I doubt that the same approach would have been applied according to the Code of Hammurabi. ${ }^{61}$ I would also question whether in the ancient period the test of the suspected adulteress would have been perceived as humiliating, whereas, as Cecilia Wassen suggests, a modern reader would so perceive it. ${ }^{62}$

not to meet this man, she hid with him, is she forbidden to live with her husband until she undertakes the ordeal.

59 Martha T. Roth, Law Collections from Mesopotamia and Asia Minor (Atlanta, GA: Scholars Press, Second Edition, 1997), 106.

6o This is a rabbinic rule, but I have no doubt that the same would apply according to scriptural rules (except the issue of the ketubah, which was established only by the rabbis; Scripture does not mention any financial compensation at a divorce).

61 The rabbis established many preliminary conditions before a woman could be brought to the priest for the test (see n. $5^{8}$ above). Further, if she claimed to have been raped, she would not be brought to the priest and could go on living with her husband (b. Ket. $5^{1 b}$ and $b . Y e b .56 \mathrm{~b}$ ), and it is evident that her claim is to be believed if the rape occurred in a place where her screaming could not have been heard (Deut 22:27). We have no way to establish whether such restricting conditions were applied in the pre-rabbinic period, although the rabbis claimed its biblical origin through a midrash. $4 \mathrm{Q}_{270}\left({ }_{4} \mathrm{QD}^{\mathrm{e}}\right)$ 4:2-4 similarly confirms that the woman's claim to have been raped is to be believed.

62 Cecilia Wassen, Women in the Damascus Document (Atlanta, GA: SBL, 2005), 61. Num 5:28b: ונזרעה זרע, translated by the NIV "will be able to have children" is interpreted in b. Sotah 26a in two modes. Rabbi Akiba says that if she was barren until now, she will become pregnant, but Rabbi Ishmael contests this, arguing that if it were so, all barren women would simulate a betrayal of their husbands, to compel them to bring their women to the priest and be granted children by God, who promised in Scripture that suspected but innocent women would be rewarded by giving birth to children; this would 
In the list of illicit sexual acts in Lev 18 and 21 and Deut 22, directed mostly towards men, there are no indications of the woman's guilt for her temptation. In Lev 18:23 and 21:15-16, the sentence of capital punishment for sodomite acts applies explicitly to man and woman alike. In Deut 22, we encounter forbidden sexual acts performed by consent of both parties, by rape, and by seduction by a man, but no rule for the case of a woman's seduction. A sole exception to the benevolent attitude of Scripture towards women is constituted by two verses in the Wisdom literature, in Eccl 7:26 and 28b; these, however, appear in the course of the author's search for wisdom and are therefore out of place for rules of conduct. Therefore, allegorical meanings of these verses have been proffered in rabbinic literature, by both traditional commentators and modern interpreters. Further, these verses do not relate to all women, but to a wicked one, as per the use of the singular in v. 26. It has its counterpoint in another maxim in Prov 18:22: "He who finds a wife finds a good thing and obtains favour from God." The rabbis reconciled these contradicting declarations, explaining that the one relates to a good wife and the other to a bad one. ${ }^{63}$ Hence, the reference in Eccl 7 does not slander the female gender as a whole, and besides has no connection to the biblical narratives of the Creation and the Fall; the possibility of detecting a negative attitude towards women in general in these verses would rather be the result of Greek influence. ${ }^{64}$

I dispute Léonie Archer's theories alleging that Scripture discriminates between the "great joy which surrounded [in scriptural narratives] the birth of a boy," and the birth of a daughter which "by no means created such a sensation." ${ }^{\prime 65}$ She quotes God's blessing of Abraham to give a son to Sarah (Gen 17:15) and Rachel's joy in giving birth to a son (Gen 30:21-24). I do not

create outrageous circumstances. Therefore Rabbi Ishmael interprets it in a more limited way: if she has had great pain at giving birth, she will henceforth have easy births, while if she has given birth only to females, she will have males in the future, and if she has had defective children, she will now have perfect children. This indicates that the rabbis were of the opinion that women would have willingly undergone the test procedure in order to become pregnant. B. Ber. 31b cites a midrash to the effect that Hanna (1 Sam 1:11) argued with God, saying that she would simulate adultery to compel God to grant her children.

63 Bird, "Images," 57-9 quotes at length all the woman's positive images in Prov and, like the rabbis, reconciles these with the denigrating quotation from Ecclesiastes.

64 Tikva Frymer-Kensky, “The Bible and Women's Studies," in Feminist Perspectives on Jewish Studies (ed. Lynn Davidman and Shelly Tenenbaum, Ann Arbor, M I: Yale University Press, 1994), 16-39 at 24 writes: "the biblical text, read with non-patriarchal eyes, is much less injurious to women than the traditional reading of Western civilization."

65 Léonie J. Archer, Her Price Is Beyond Rubies: The Jewish Woman in Graeco-Roman Palestine (Sheffield: јsот, Supplement Series 6o, 1990), 17-18. 
think that Archer's biblical citations should be perceived as discriminatory of women; they represent a customary natural fact and human aspiration. Anthropological attributes shaped the desire of humans to leave offspring. According to the creation narrative and biological reality, as understood in ancient times, it is the man who inseminates the woman. Scripture uses the term זרע "seed" in its portrayal of procreation; God tells Abraham that his offspring will be counted through Isaac, and that he will also make Ishmael into a nation, because he is Abraham's offspring, although born of a maidservant (Gen 21:12-13). His seed procreates his offspring in the womb of the woman; hence, in this cultural view, only a son ensures humanity's craved "immortality" or eternal life as the ongoing initiator of the eternal procreation process. ${ }^{66}$ The lesser enthusiasm at the birth of a daughter is not the result of women's inferiority, evil character, or lack of wisdom, but the result of the biological fact as perceived by the biblical authors that man's seed is the core of the offspring. Zelophehad's daughters approached Moses because they were concerned that their father's name would disappear because he had no sons (Num 27:4). A similar instance is found in the levirate rule that commands the brother to marry the widow of his deceased brother who had no son "so that his name will not be blotted out from Israel." 67 These circumstances reveal the true motive behind these and similar biblical citations that indicate the craving for a son; ${ }^{68}$ it does not signify female inferiority, but is rather the consequence

66 Ibid. at 22 quotes Ben Sira among slanderers of women such as Josephus and Philo; however, she cites also his quotation: "When his father dies, he dies not altogether, for he has left one behind him like himself."

67 The levirate law is activated when one of the brothers living together dies ובן אין לו "without having a son." Sifre piska 288 interpreted here the term בן as a child, regardless of whether the child is a son or daughter, and the Lxx likewise translates the term with the neutral $\sigma \pi \dot{\varepsilon} \rho \mu \alpha$ "seed or 'offspring.' " The term הבכור in v. 6 is a definite masculine denominator, since there is no concept of a first-born female in Scripture, but nevertheless the LXx equally translates it as the undefined $\pi \alpha$ เoiov "a young child." A daughter could not fulfil the task of carrying on the name of her father, the motive of the levirate indicated in Num 25:6. In marrying another man, she would cause him to inherit the land of her deceased husband, whose name would be blotted out. In their period, the rabbis were already against the performance of the levirate marriage, because of practical problems (m. Bek. 1:7). Therefore, it is no wonder that they accordingly adjusted the interpretation of the scriptural text in order to reduce the consummation of such marriages, without explicitly changing the biblical rule.

68 Carol Delaney, "Abraham and the Seeds of Patriarchy" in The Feminist Companion to the Bible (Second Series; ed. Athalya Brenner, Sheffield: Sheffield Academic Press, 1998), 129-149, at 139-140 states: "The male was imagined as the generator and transmitter of seed, the vehicle for the transmission of life itself. His was the engendering, creative role. 
of the fact that a woman cannot ensure the transfer of the family's inheritance to the offspring or ensure the propagation of the familial lineage, because at her marriage she loses her separate legal identity. ${ }^{69}$ The narrative of Ruth the Moabite, recording that King David, founder of the revered and perpetual Davidic dynasty, was her offspring, demonstrates that in marrying Boaz, an Israelite, she lost her ethnic identity and became Israelite. Boaz did not transgress in marrying Ruth, even though male Moabites, who retain their ethnicity, are precluded from joining the Israelite people (Deut 23:4). ${ }^{70}$ In other favourable biblical citations we encounter equality between males and females, such as for example in Gen 5:1-2. In Gen 5:4-30, 46:7; Exod 10:9; Deut 7:13 and 16:14, sons and daughters are equalized. In unfavourable circumstances, Deut 28:41 similarly equalizes the pain of the loss of sons and daughters. The woman is "Equal in Being, but Different in Function," as Rebekah Groothuis describes the traditionalists' view. ${ }^{71}$

I would speculate that the predisposition to attribute gender discrimination to Scripture has induced exegetes to ignore favourable biblical citations and to interpret neutral ones tendentiously to be appropriate to such a thesis. ${ }^{72}$ I was led to this idea by Archer's statement that "In the early strands of the Old

Paternity, then, is a particular construction of the male role, not just recognition of a biological connection," and "In this theory, it is only sons who have the power to generate seed and transmit it; hence the central importance of sons."

69 Bird, "Images," at 56 characterizes the woman's status in terms of "a legal non-person." I do not agree with her statement that the woman's dependent status is usually inferior; this does not logically follow from her dependent legal status.

70 We read in b. Yeb. $76 \mathrm{~b}$ that the prohibition in Deut 23:4 to absorb Ammonites and Moabites refers to males, not to females: עמוני ולא עמונית מואבי ולא מואבית. Modern scholars do not acknowledge this rabbinic solution to the dilemma, and postulate different solutions to the apparent conflict between Deut 23:4 and Ruth 4:18-22, as they perceive it. I believe, however, that the rabbinic opinion is correct, since at her reunification through marriage with her primeval source Ruth becomes part of her husband. In this connection one could cite Solomon's marriage with Pharaoh's daughter, perceived as an indication of his high rank in 1 Kgs 3:1, where there is no suggestion of criticism of it. The negative attitude towards his foreign women, including Ammonite and Moabite women, in 1 Kgs 11:1-11 is due, not to their ethnicity, but to their evil influence on him, resulting in his idolatrous worship.

71 Rebekah Merrill Groothuis, Good News for Women: A Biblical Picture of Gender Equality (Grand Rapids, MI: Baker Books, 1997), 41.

72 Wegner, "Philo's Portrayal of Women," at 43 makes the same observation regarding selective quotation of rabbinic statements; scholars cite those unfavourable to women and ignore those who show women in a positive light. 
Testament even incest was condoned if it were to produce male offspring."73 She refers to the narrative in Gen 19:31-38, recording how "the daughters of Lot, in the absence of other men, contrived to lay with their father in order to preserve his seed, and by their union succeeded in having two sons, Moab and Ben-ammi [Ammon]." I do not perceive scriptural compliance with their act; while the text here is neutral towards it, we can deduce Scripture's attitude towards these two peoples, the outcome of Lot's daughters' act, from Deut 23:4: "An Ammonite or a Moabite shall not enter into the assembly of the LORD even to the tenth generation shall none of them enter into the assembly of the LORD,${ }^{74}$ even to the tenth generation," with an additional exhortation "forever" (translation KJV, v. 3). ${ }^{75}$ At any rate, there is nowhere in Scripture the slightest hint of acquiescence to Lot's daughters' action. According to my opinion, Scripture perceives their act as extremely wicked. I do not contest Archer's thoughts about Jewish conceptions in Graeco-Roman Palestine regarding women; this is not in the ambit of my research. I do however dispute her interpretation of the scriptural citations she quotes.

The key question is: does discrimination denote a lower evaluation and subsequently a different management of women's rights and interests, such as we have seen in the Hammurabi Code, or does it rather represent a distinction in their functions without any deliberate discrimination for the worse ${ }^{76}$ The narrative of the three visitors to Abraham in Gen 18:2-9 offers us an instance of the scriptural distinction between the functions of man and woman; Sarah

73 Archer, Her Price, 18.

74 The repetition may indicate Scripture's abhorrence in this matter.

75 Scripture justifies this extraordinarily harsh rule against these two nations: "For they did not come to meet you with bread and water on your way when you came out of Egypt, and he hired Balaam son of Beor from Pethor Aram Naharaim to pronounce a curse on you. (Deut 23: 5)." However, in contrast to other alien nations that have no limitations on entering the assembly of the Lord, or the Edomites and Egyptians who are allowed to join Israel after three generations, the Ammonites and Moabites are eternally excluded. The justification indicated in Scripture for their perpetual rejection shows literary and logical irregularities, and altogether throws a great doubt on its reliability. This is not the place to delve further into speculations about the real motive of this severe discrimination, but the contingency that it was the result of their incest genealogy seems plausible. See an extensive study about this issue and another hypothesis of its motive by Paul Heger, "Unabashedly Reading Desired Outcomes into Scripture," in Vixens Disturbing Vineyards: Embarrassment and Embracement of Scriptures; Festschrift in Honour of Harry Fox (leBeit Yoreh), (eds. Tzemah Yoreh et al., Boston: Academic Studies Press, 2010) 96-139, at 108-118.

76 See, however, the discussion of discrimination in $\mathrm{n} .53$. 
carries out her duties in the house, while Abraham greets and hosts the visitors, fulfilling his traditional Bedouin duty of hospitality, and asks Sarah, who is in the tent, to prepare the meal for them from the calf he has provided. Sarah remains in her tent even when the angel promises that she, not he, will have a son. The different functions do not suggest that Sarah suffers disadvantageous discrimination. The women were not obligated to fulfill all the precepts which the men must accomplish; this distinction, however, should not be perceived as a negative discrimination. In Chapter 1 I discussed at length the motivation for and legal consequences of the woman's loss of her individual identity at marriage, and demonstrated that it is not the result of her inferiority or of negative discrimination. The same applies to the fact that a man may have many wives, but a wife can have only one husband. It reveals the social realities of the time, without any implication of different evaluations of man and woman. The biblical rule about witnesses appears in the masculine plural: "on [the testimony of] two witnesses" (Deut 17:6), but this does not absolutely indicate that according to Scripture women cannot act as witnesses. At any rate, such a restriction, if indeed the intent of Scripture, should not be perceived as a result of women's intrinsic inferiority.

\subsubsection{Excursus: Is Jubilees' Attitude towards Women Negative or Positive?} In contrast to my argument that the author of Jubilees had a preconceived negative attitude toward women, indicated by his changes deviating from the scriptural text in significant details, Betsy Halpern Amaru ${ }^{77}$ has concluded that other changes demonstrate a more positive attitude towards women in Jubilees than that shown by the Priestly biblical author. While I shall not critically analyse all the problematic aspects of her thesis contradicting my comprehension of Jubilees' intent in its changes of the biblical text, a few examples may be demonstrated. Her first significant error, as I see it, is the attribution of the second Creation and the Fall text to the Priestly writer, whereas it is commonly assumed to be the writing of Y and J. Only the creation story in Gen 1, which as I have argued is the most egalitarian Creation narrative, is assumed to be the work of the Priestly writer. To substantiate her thesis, Halpern Amaru states that Jub. 2:14: "He created man, a man and a woman He created them" repeats verbatim Gen 1:27, but she ignores the omission of the crucial phrase

77 Betsy Halpern Amaru, “The First Woman, Wives, and Mothers in Jubilees," JBL 113/4 (1994) 6o9-626, at 609 writes: "The author of Jubilees demonstrates an interest in women in sharp contrast to that shown by the Priestly biblical writer ... certain facets of the reworking of the Genesis narrative in Jubilees might even be understood as in sympathy with some contemporary feminist reading of the biblical text." 
that both were created in the likeness of God. Further, she overlooks the deviations in Jub. 3:15-16 from the biblical text in the subsequent vv. Gen 1:28-29, detrimental to the woman's rights and equality, as amply demonstrated above. Moreover, we cannot deduce the general attitude to women in Scripture from the exalted portrayal of the Matriarchs; just as the Patriarchs are sui generis, and do not reflect on the status of their descendants, so are their first wives. ${ }^{78}$ We see, for example, that Jubilees confers on Rebekah a certain type of prophecy, a particular faculty typical of the Matriarchs. Whereas Gen 27:42 records that "the words of Esau her elder son [intending to kill Jacob] were told to Rebekah," without any indication of how she became aware of his intentions, "said to himself (in secrecy)," Jub. 27:1 adds that they were told "in a dream" to Rebekah. Halpern Amaru draws our attention to the statement in Jub. 3:21 that Eve first covered herself and only then gave the fruit to Adam; she perceives this statement as a "highly complimentary one which emphasizes her modesty... [showing] a greater awareness of the woman as a character and a more sympathetic view of her [than in Scripture]."79 She does not consider the notion that this is just a required correction of an inconsistency in the biblical text; since she ate the fruit first, her eyes opened immediately, and it is only logical that she was ashamed of her nakedness and covered herself before going to meet Adam and giving him the fruit. The biblical expression: "then the eyes of both of them were opened, and they realized they were naked" (Gen 3:7) does not convey the circumstances correctly, and the author of Jubilees corrected it, as has been done in similar circumstances elsewhere. He explains, for example, why Reuben was not executed for lying with Bilhah, his father's concubine (Jub. 33:16). I do not think that one can build on a technical correction by the Jubilees author a speculative theory of his intent to exalt Eve's behaviour,

${ }_{78}$ Compare the significance of Sarah and her child to that of Hagar and Keturah and their children, and more so the distinction between the Matriarchs. There is an apparent difference between the status of Jacob's children born to the Matriarchs Leah and Rachel and those born to their maidservants Bilhah and Zilpah. Although the latter are certainly the mothers of four Israelite tribes, they are not counted in the traditional writings and in the liturgy among the mothers of the Israelite people. We read in b. Ber. 16b: "We learned in a baraita: One does not call [our] fathers except [the] three [Abraham, Isaac and Jacob], and one does not call [our] mothers except [the] four [Sarah, Rebekah, Rachel and Leah]." In Gen 33, at their presentation to Esau, the mothers Leah and Rachel are mentioned by their names, whereas Zilpah and Bilhah are merely called the "maidservants." It also seems that the tribes descended from the maidservants are likewise perceived as being of a lower rank. They stand on Mount Ebal for the curses (Deut 27:13), in contrast to the great majority of the Matriarchs' sons standing on Mount Gerizim for the blessings. 
particularly when the same author, as we have seen, used all available means to emphasize her guilt in the Fall.

Adding to the narrative details such as God being angry with Eve because she listened to the voice of the serpent, an accusation absent in Scripture, indicates clearly Jubilees' intended portrayal of the woman's principal involvement in the Fall narrative, whereas Halpern Amaru's conjectures regarding the name-giving are founded exclusively on her speculation and have no tangible basis in Jubilees' text. Giving names to females does not indicate their significance, as she claims; ${ }^{80}$ Jubilees adds in its narratives a great array of details absent in Scripture, like the date at which Adam had intercourse with his wife, without mentioning her name (Jub. 4:7), whilst at the birth of his additional nine sons, Jubilees does not indicate the dates, but does mention Eve as his wife. Similarly, Jubilees mentions Enosh's date of birth (4:11), but omits the more important event of his father Seth's birth (4:7). The recording of the mothers' names does not imply the author's deliberate intent to indicate their equality with men, being similar to his haphazard recording or omitting of the dates of birth of sons and daughters. Although Halpern Amaru is aware of the wicked meaning of the name Aven (Sin) given to Adam's daughter and Cain's wife in Jub. 4:1, she considers it as "an indication of the significant role of women in the genealogical records of Jubilees," ${ }^{\prime 1}$ ignoring the contrary deduction that naming her "wicked" implies that she, the woman, is jointly responsible in Cain's sin; contrast this with the scriptural account, which does not divulge her name. Moreover, the first three doomed children, whose genealogy ends in the fifth generation, are attributed in Jub. 4:1 only to Eve; Adam is not mentioned as their father, and the wicked daughter Aven, as her name implies, is singled out as Eve's daughter. In contrast, at the birth of Seth, in Jub. 4:7 and 9, the father of future humanity, Eve's name is not mentioned, and both Seth and his sister Azura are denominated as Adam's children. In comparison, Gen 4:25 emphasizes Eve's involvement in Seth's birth and naming and the divine favour shown to her in granting her "another child in place of Abel" (Gen 4:25). Halpern Amaru makes the argument that in Jub. 4:8 Adam uses Eve's words at her naming of Cain, demonstrating her significance, but this cannot compensate for the array of texts that indicate the opposite. ${ }^{82}$ In Gen 4:25, Eve thanks God, saying: "God has granted me another child," whereas in Jub. 4:7 Adam thanks God, saying: "'God has raised up a second seed unto us on the earth instead of Abel." Adam is portrayed as the essential player of this

\footnotetext{
$80 \quad$ Ibid., 614-615.

81 Ibid., 614.

82 Ibid., 614-615.
} 
significant event, the birth of the father of humanity: the undefined she, without name, bore him a son, whom he named and thanked God for.

Halpern Amaru attempts to reverse the simple meaning of the text on this occasion while ignoring the many changes the author of Jubilees effected in order to indict the woman for the world's calamities, as already discussed. I believe that the slander of Eve in Jubilees is a better indication of the author's attitude towards women than giving names to women. In effect, we do not know the author's intent and motive for giving names to the women, and Halpern Amaru's assumption that his objective was the emphasis of the woman's significance is pure speculation on her part. In contrast, Jubilees' many deliberate changes to Gen 2 and 3, as detailed in section 2.2 .3 above, clearly demonstrate the author's bias against women.

It seems to me that Halpern Amaru perceives the recording of the women's names in Jubilees as overriding evidence of Jubilees' "co-equal" participation of the woman in the narrative, 83 and this leads her to interpret inversely to their straightforward meaning all the many changes effected to the detriment of the woman. The "co-equality" of the woman in the Fall narrative, perceived by Halpern Amaru as favourable to the woman, has the opposite effect; in contrast to the biblical text, which blames mainly Adam, shifting the blame towards the woman resulted in attributing the primary guilt to her. Last but not least, the author of Jubilees adds a great array of details to many other personages, as for example to Ishmael, in whose case I can only speculate that as Abraham's son, he intends to grant him greater significance. This preference is associated with his personal status, not unlike the naming of the Patriarchs' wives, and thus does not indicate appreciation of women in general. I therefore reject Halpern Amaru's speculation regarding Jubilees' preferential attitude towards women.

I would likewise dispute Kelly Bautch's endorsement of Halpern Amaru's assertions aboutJubilees' magnification of women. ${ }^{84}$ She adds for example the fact that Jubilees supplies the names of Cain's and Seth's wives, which Genesis does not supply. She does not consider the consequences of the meaning of the names devised by Jubilees, as with those devised by other ancient authors. She correctly recognizes that the name of Cain's wife Avan, really Aven, like the Hebrew און "sin” in Jub. 4:9, indicates the author's aim to imply wickedness, but does not connect it with the reason for Cain's line not extending beyond his death. I cannot speculate on the meaning of the name Azura, Seth's wife,

$83 \quad$ Ibid., 612.

84 Kelly Coblenz Bautch, "Amplified Roles, Idealized Depiction: Women in the Book of Jubilees," in Enoch and the Mosaic Torah: The Evidence of Jubilees (ed. Gabriele Boccaccini and Giovanni Ibba; Grand Rapids, MI: Eerdmans, 2009) 338-52, at 340-44. 
since it is not known how the original Hebrew name was written. We have theophoric names among those devised by Jubilees, and names with other meanings that plausibly indicate the reason for which they were chosen, as Bautch also notes. Hence, it is evident that the author of Jubilees did not decide haphazardly which women and wives to name and which to ignore, and the meaning of the devised name, wherever we are able to reveal it, is the key for comprehending his choice. I hypothesize, for example, that he indicates the name of Seth's wife because she bore Enosh at the time when men began to call on the name of God (Gen 4:26), and the Patriarchs were his descendants. We see, for example, that he did not name Ishmael's wife, although he grants much more detail and importance to Ishmael than Scripture. He minimizes the significance of Esau's wives: whereas Scripture indicates the names of Esau's Hittite wives (Gen 26:34), Jub. 27:8 ignores their names, and records only that they were daughters of Heth. Even when Jub. $29: 18$ indicates the name of Esau's third wife, Ishmael's daughter, he does not amplify her exalted genealogy, as Gen 28:9 does, recording her ancestry from Abraham. We may observe here also Scripture's choice of her name Mahalat, from the root חלה, implying sickness, similar to the names of Elimelech's two sons Mahlon and Kilion (Ruth 1:2), which imply sickness and extinction. We observe that Jubilees' naming of women does not relate to their significance as wives as such, but has specific and defined purposes.

Bautch interprets the severe criticism of exogamy in Jubilees as implying the significance of the woman or wife, but this does not seem to me to be justified. The Jubilees author lived in the period after Ezra and Nehemiah, who extended the biblical prohibition against intermarriage with Canaanites to all Gentiles and imposed drastic measures, such as the expulsion of these women and their children. This ruthless act was undertaken to avoid the evil influence of intermixing with Gentile society through intermarriage, as we observe in Ezra 9:1 and in Neh 13:26, which compares their intermarriage to King Solomon, whose foreign women caused him to sin. The intermarriage prohibition does not imply a greater significance for women than in other prior books of Scripture.

I agree, however, with Bautch's assertion that Jubilees reconciles biblical contradictions, as for example the two different creation narratives in Gen 1 and 2, but she overlooks that in unifying the two narratives, the author of Jubilees alters the woman's involvement in the Fall narrative; from an innocent party he turns her into a guilty one. I contend that the author's resolution of the two narratives was not driven by his quest for reconciliation of the biblical inconsistency, but by his intent to convict the woman rather than the man as the primary perpetrator of the transgression of the divine command, 
as demonstrated above. Van Ruiten, who, as we have seen (pp. 61-63), does not perceive many of Jubilees' alterations of the biblical text as an attempt to modify the positive biblical view of the woman by overturning it to Adam's better advantage, argues that Jubilees' claim at 3:21-22 that Eve covered her nakedness before approaching Adam, in contrast to Gen 3:7, demonstrates that she watched Adam's nakedness. Van Ruiten ignores the idea that Jubilees' emendation could be perceived here as merely a logical correction of the existing text, since Eve ate the fruit first and her eyes opened first. ${ }^{85}$ Although he admits that "the author of Jubilees ... has a very positive view of Adam," ${ }^{\text {86 }}$ he overlooks this bias, and searches for other dubious and unconvincing harmonizing or explanatory solutions to reconcile between the scriptural and Jubilees texts. Even his admission that Jubilees "gives a rationale for the curse of the woman, which is not present in the text of Genesis" does not induce him to conclude that many of Jubilees' changes of and omissions from the biblical text result from the author's evident bias towards Adam. He downplays the crucial difference between the texts of Jub. 3:26c asserting that God "sent them [both Adam and Eve] forth from the Garden," and of Gen 3:23a that God "banished him [only Adam]," claiming that "the text of Jub. 3:26c is a verbatim quotation from Gen 3:23a with some modifications." ${ }^{87}$ Finally, I strongly dispute van Ruiten's speculation that the omission of Gen 3:22-24 is due to the author of Jubilees having a different Vorlage before him. ${ }^{88}$ There is no valid reason for such a drastic statement, given that logical considerations explain the differences.

\subsubsection{Intermediate Summary}

I have offered what I believe to be a logical explanation of the adjustments and omissions of these verses, like those of other similar ones, in terms of deliberate changes made by Jubilees' author to ameliorate the stain on Adam's character in the Fall narrative and its moral and functional ramifications, specifically to the detriment of Eve.

\footnotetext{
85 Van Ruiten, Primeval History, 95-96.

86 Ibid., 98.

87 Ibid., 104 .

88 Ibid., at 104 writes that the omission of Gen 3:22-23b, 24 could be seen as an attempt to harmonize "contradictions between the biblical story and traditions not documented in the Bible - traditions that were authoritative for the author of Jubilees."
} 


\subsubsection{Hypotheses of Woman's Role in the Fall Event}

Since there are no interpretations of the relevant biblical text in Qumran writings, we can only deduce implicitly from their writings, and from the premise of their generally straightforward interpretation of Scripture, that they followed the biblical texts in not perceiving the woman as the main culprit of the Fall, being possessed of a wicked character.

4Q416 (4QInstr ${ }^{\mathrm{b}}$ ) 2 iv:1-4 seems to confirm this proposition. We read there:

And should $\mathrm{cl}$ [eave to his wife, So that they (...?) should become one flesh].Thee has He set in authority over her, And she shall o[bey thy voice and Her father (?)] He has not set in authority over her; From her mother He has separated her, But towards thee [shall be her desire, And she shall become] for thee one flesh.

We observe that the author uses in his introductory argument the biblical citations from the woman's creation (Gen 2:24) to support the core of his thesis about the relationship between man and woman in its various aspects. Thus, as it seems, he does not perceive man's domination over his wife and her desire for him as a punishment for a major role on her part in the transgression of the divine command not to eat the fruit from the forbidden tree, ${ }^{89}$ but as a result of her creation from man, similarly to my own interpretation of Gen 3:16, a verse that, as has been remarked, seems out of place in the midst of the punishment verdicts of Adam and the serpent. Consequently, following this line of thought, one may hypothesize that the author of $4 \mathrm{Q}_{416}$ disagreed with Jubilees' scheme of attributing to the woman an important role in the transgression of the divine command. In light of this presumed interpretation of $4 \mathrm{Q}_{416}$, I tend to conjecture that its author relieved the woman from the responsibility of the Fall and its aftermath. Such a difference in the interpretation of a narrative should not be a surprise; although Jubilees was revered in Qumran, it does not follow that Qumran must agree without exception on every point of Jubilees' interpretation of biblical narratives, particularly regarding the creation narratives that have no role in Old Testament and Jewish lore, in contrast to their importance

89 Tal Ilan, "Women in Qumran and the Dead Sea Scrolls," in The Oxford Handbook of the Dead Sea Scrolls (eds. Timothy H. Lim and John J. Collins, Oxford: Oxford University Press, 2010) 123-147, at 129 writes: "the biblical intertext [in 4Q416 2 iv:1-4] however, is not treated as evidence that women are intrinsically evil, as we find in Ben Sira (25:24) and in early Christian renderings of this story." 
in Christian doctrine. ${ }^{90}$ As I have written elsewhere, ${ }^{91}$ Qumran writings never quote support from Jubilees' halakhot, even in their polemic halakhot agreeing with Jubilees' rulings; ${ }^{92}$ their quotations from Jubilees concern exclusively doctrinal and prophetical topics. ${ }^{93}$ Hence, there are significant grounds for considering the possibility that Qumran interpreted the Creation and Fall narratives differently thanJubilees, since its interpretive method was founded on the premise that "everything in the Torah is laid out in detail," that is, to be understood in a direct manner.

Notwithstanding this, however, we cannot exclude the contingency that Qumran agreed with a possibly dominant opinion in that period that Eve, in her compliance with the serpent's advice, was the primary agent of the calamity. The acknowledgment of this viewpoint does not imply that Eve seduced Adam to eat the forbidden fruit as transpires from the rabbinic literature (since this is not asserted in Scripture), and even less so that women of future generations are wicked or dangerous seductresses. Hence, in any event, there would be no incongruity between Qumran's possible perception of Eve as the primary initiator of the Fall event and therefore responsible for it, and the

9o Westermann, Genesis at 42 writes that in contrast to the teaching of Gen 2-3 about the Fall that played an important role in Christian tradition, "they have no corresponding role in the Old Testament where they scarcely appear," because in Jewish tradition "creation is a primeval event and not the beginning of history." Israelite theology does not acknowledge the concept of "a primary sin," and Eve's sin or wicked behaviour as alleged by the rabbis has no lasting influence on women's character. The slanderous rabbinic portrayal of contemporary women is not associated with Eve's sin and character; they are perceived as two distinct issues. Lyn M. Bechtel, "Rethinking the Interpretation of Genesis 2.4b-3.25," in A Feminist Companion (ed. Brenner) 77-117, at 78-79 disputes the traditional interpretation of the relevant narrative as a "sin and fall" event, demonstrating the many problems associated with this style of interpretation, since the "most compelling reason" for this interpretation "is the fact that Adam and Eve and the Gen 2.4b-3.24 myth in general are not used elsewhere in the Hebrew Bible as an example of sin." Thus, she does not take account of Westermann's observations on the character of "primary sin" in Jewish tradition.

$91 \quad$ Heger, Challenges, 219.

92 Whether the narrative of Jub. 3:8-13 was the source of 4Q265 (4Q Misc Rules) VII:11-17, as Florentíno García Martínez, Qumranica Minora II, Thematic Studies on the Dead Sea Scrolls (ed. Eibert J.C. Tigchelaar, Leiden: Brill, 2007) at 73 argues, or whether alternatively $4 \mathrm{Q}_{2} 65$ used the same source that Jubilees used, as Martha Himmelfarb, "Sexual Relations and Purity in the Temple Scroll and the Book of Jubilees," DSD 6, 1 (1999) 11-36 at 25 argues, neither possibility contradicts our assertion, since neither Jubilees nor $4 \mathrm{Q}_{2} 65$ pronounce a halakhah; they merely explain the motive of the scriptural halakhah in Lev 12:2-5. 
notion that this circumstance was not the result of Eve's wicked character. One could rather conjecture that according to Jubilees and Qumran the serpent succeeded in convincing the woman to taste the fruit, because of her weak and docile character. The scriptural text does not allude in any way to enticement on Eve's part in giving the fruit to Adam, while there is no reason from the text to perceive Eve, and women in general, as predisposed to seductive behaviour leading to wickedness or moral corruption, as the rabbis suggest. In fact, we do not encounter derogatory opinions about women in Scripture, in Qumran, nor even in Jubilees, despite its unfavourable attitude towards Eve, attempting as we have seen to attribute to her a greater element of guilt than appears in Scripture. Based on the close textual analysis in sections 2.2.1 and 2.2.2, Scripture indeed indicates neither Eve's central involvement in the Fall, nor a punitive character in God's communication to her.

\subsubsection{No Allegation of Sexual Misbehaviour of Women in Qumran Writings}

The apparently overwhelming criticism of sexual misdeeds in Qumran writings does not accuse women of a seductive character that corrupts men, instigating them to immoral behaviour, such as we encounter in rabbinic literature and instructions. ${ }^{94}$ The woman is not perceived as a danger to virtuous life of society. Qumran rather accuses men of walking in the stubbornness of their heart שרירות לב (CD III:11) and of practising fornication, falling into the trap of Belial (CD IV:15-17). Indeed, at the severe criticism of the Watchers in CD II:16-21, there is no accusation against women for seducing them or similar denigrating expression of the women; the entire blame is on the men who went about in their willful hearts and did not observe God's commandments. The three traps in CD IV are directed to man and his deficiencies in withstanding his evil inclinations; again, women are not accused in this lemma. Qumran criticized man's lack of ability or willpower to behave properly, and to avoid walking in the stubbornness of their hearts.

CD XIII:15-17 compares man's lust and greed and has therefore enacted the provision that the members of the Community must act on these matters solely under the supervision of the Controller. We read there: "No one should do any buying or selling unless he has informed the overseer who is in the camp, and he shall do [ ] marries a woman and [ ] counsel and so to a

94 Ilan, "Women in Qumran," 129-130 suggests that although Qumran knew and preserved Ben Sira's writings, "the Qumranites were not interested in ... his approach to women (of which they preserved no fragment)." 
divorced man [or better 'anyone who divorces']."95 Qumran's severe criticism regarding sexual mischief is directed exclusively against man's מחשבת [זמס], translated as "lustful thoughts" $\left(4 \mathrm{Q}_{2} 66\left(4 \mathrm{QD}^{\mathrm{a}}\right)\right.$ 6i:15 and 4Q272 (4QD') 1ii:4), but does not seem to accuse women of similar misbehaviour. ${ }^{96}$ This preconceived opinion stems from the biased interpretations of the Fall narrative and of successive narratives, as for example the rabbinic midrashim about Dinah's indecent behaviour, cited later in the chapter (see pp. 93-94), but it has no real basis in scriptural or Qumran evidence. ${ }^{97}$ The physical examination of the bride in $4 \mathrm{Q} 271\left(4 \mathrm{QD}^{\mathrm{f}}\right)$ 3:12-15 refers solely to a woman with a bad reputation, and should be perceived as advantageous for such a woman, permitting her to restore her good name..$^{98}$ This is not the place to enter into an extended discussion about Qumran's interpretive system and whether their halakhah is more stringent than that of Scripture, but suffice it to say this is a general problem, without any specific emphasis regarding women or sexual issues.

I assume that Qumran, abiding systematically by a simple exegesis of Scripture, ${ }^{99}$ deduced woman's natural right to a regular sexual life from the dictum of Exod 21:10: "If he marries another woman, he must not deprive the first one of her food, clothing and marital rights." I would even go a step further and hypothesize that Qumran complies with the divine proclamation to Eve: "Your desire will be for your husband." The Hebrew term תשוקה in

95 The first version of this phrase is E. Cook's translation in the DSSEL, but I prefer in this case the translation of Florentino García Martínez and Eibert Tigchelaar in The Dead Sea Scrolls Study Edition (Grand Rapids, MI: Eerdmans, 1997), reading "anyone who divorces."

96 The text of both lemmas is corrupt. Although it seems that the dictum intends to declare a man impure for having lustful thoughts, it suffices to perceive Qumran's condemnation of the man, in contrast to a more lenient approach towards the woman.

97 Qumran's recommendation not to marry a woman who was sexually active before her marriage and had a bad name, appearing in $4 Q_{2} 71\left(4 Q^{f}\right)$ 3:10-13, does not make "female sexuality a dangerous force" (Wassen, Women, 207). Such behaviour was considered immoral at that time and the close-knit community of Qumran wanted to avoid the absorption of such unchaste elements, incompatible with the general spirit of the community. In fact, the Controller regulated everything in the life of the group; his permission had to be sought "to bring anyone into the group (CD XIII:13)."

98 Wassen, Women, at 208 also perceives this as a positive ordinance intended "to avoid a situation described in Deut 22 in which a woman can face the death penalty after the wedding."

99 Crawford, "Not According to Rule," $127-50$ at 131 asserts that since the Qumran legal texts are largely compatible with each other, "it is methodologically appropriate to treat them systematically." 
connection with a woman must be interpreted here with a sexual undertone of lust, ${ }^{100}$ similarly to the term in Cant 7:11 (10 in KJV) in the context: "I belong to my lover and his desire [תשוקתו] is for me," where it relates to man's desire for the woman. Hence, God has instilled in the woman the sexual lust for a man, and therefore such a trait is legitimate and should not be perceived as wicked. ${ }^{101}$ Scripture does not indicate whether man's lust or sexual desire is also inherent as an element of his creation, but one should expect this to be the case in order that man may fulfill his obligation to satisfy woman's legitimate desire, and it is implicit in the above verse of Canticles. Indeed, it seems that there is no criticism of man's love of his wife, which definitely does not exclude its sexual aspect, and which we encounter in Isaac, whose love for Rebekah consoled his grief over his mother's death (Gen 24:67), and in Jacob, who fell in love with Rachel because she was "lovely in form and beautiful," the seven years he worked at Laban for Rachel "[seeming] to him only a few days because of his love for her" (Gen 29:17-18).

The fact that the Qumran scholars respected women can be indirectly אל תקל כלי [ ח]יקכה deduced from their writings. However, if the phrase (4Q416 (4QInstr ${ }^{\mathrm{b}}$ ) 2ii:21) is correctly translated and interpreted by J. Strugnell and D. Harrington, $\mathrm{SJ}^{102}$ as "do not treat with dishonour the 'vessel' (or 'wife') of thy bosom,"103 then we have clear and direct evidence of Qumran's positive attitude towards women. ${ }^{104}$ This assertion is further enhanced by Qumran's instructing the women on the rules of the Covenant, as we read in $1 \mathrm{Q}_{2} 2 \mathrm{a}$ (1QSa) I:4-5.

Though heavily damaged, 4Q502 (4Qpap Ritual of Marriage) Frags. 1-2, assumed to be related to a marriage celebration, ${ }^{105}$ offers us an indication

100 See n. 24 p. 53 regarding a possibility that some mss had the term תשובתך "your return" in place of תשוקתך "your desire."

101 According to Mek. Yethro, Mass. D'beHodesh, parsha 8 the tenth commandment not to covet one's wife, house, etc. applies only if one takes action as a result of it, but the desire alone is instilled by God in humans, and does not represent a sin.

102 DSSEL.

103 García Martínez and Tigchelaar, Dead Sea Scrolls Study Edition, do not include the phrase "(or 'wife')" in their translation.

104 Eileen Schuller, "Women in the Dead Sea Scrolls," in The Dead Sea Scrolls after 50 Years: A Comprehensive Assessment (ed. Peter W. Flint and James C. VanderKam; Leiden: Brill, 1998) Vol. 2, 117-144 at 138 writes that "the obligation not to disdain one's parents (Deut 27:16) is extended to one's wife." I do not find such a comparison in this text.

105 Maurice Baillet, 4.III (4Q482-4Q520) DJD VII (Oxford: Clarendon, 1982) 81-105 names it "ritual de marriage." Joseph M. Baumgarten, “4Q502: Marriage or Golden Age Ritual," JJs 34 (1983) 125-35 favoured its comprehension as a "Golden Age separation ritual." Michael L. 
of the realities practised within the group. It depicts an idyllic harmonious communal life, in which all of its members, men and women, young and old, participate without any discrimination and without any fear of female temptation. We encounter there expressions about the holiness of sexual intercourse for the engendering of children and praise for the value of women, who make this possible, for which man has to thank God for his righteous and wise wife. ${ }^{106}$ We observe the equality of men and women at the participation of such joyous events. ${ }^{107}$

\subsection{The Rabbinic Interpretation of the Fall Narrative}

\subsubsection{Midrashim with Negative Views towards Women}

The rabbis did not interpret scriptural texts continuously, verse by verse, as did the later traditional commentators who used the rabbinic midrashim in their interpretations. ${ }^{108}$ Therefore we can only deduce a plausible rabbinic interpretation of the relevant biblical narrative of the Fall by examining occasional rabbinic interpretations, midrashim, halakhot, and instructions for conduct with women. In doing so, I shall quote numerous midrashim, some of which combine the Creation and Fall narratives. The overwhelming majority of the midrashim and rules of conduct portray a negative image of woman's character, albeit with nuances in their severity, and accuse the woman of instigating

Satlow, “4Q502 A New Year Festival?" in DSD 5 (1998) 57-68 suggested it relates to a New Year Festival. Aharon Shemesh, "Marriage and Marital Life in the Dead Sea Scrolls," in The Dead Sea Scrolls and Contemporary Culture: Proceedings of the International Conference Held at the Israel Museum, Jerusalem (July 6-8, 2008) (ed. Adolfo D. Roitman et al.; Leiden: Brill, 2011), 589-60o at 592 convincingly defends Baillet's classification, which I have adopted.

106 We read there: "a m]an who acknowledges[; law of God; a man] and his wife for; ] to produce descendants[;] [ ]which; from being hol[y; his spouse wh[o; intercourse of; for righte[ous] children; the] holy, give thanks to God; to him a reliable woman who wa[lks; wisdom and insight among; to]gether to be; of God, and atoning."

107 We read in 4Q502 (4Qpap, Ritual of Marriage) 19:1-4: "So let him dwell with him in the council of [the ]h[oly ones ] descendants of blessing, elder men and [women young men] and virgins, boys and gi[rls with all of us together."

108 For example, the medieval commentator Rabbeinu Behaye, commenting on the phrase "the serpent was the most shrewd" in Gen 3:1 at the end of the fourteenth century, explains that Satan was born with the woman, a body of bad impulses and easily seducible. See in n. 105 p. 42 of Chapter 1 the opinion of a late traditional commentator Hatam Sofer about women's inferior wisdom. 
the tragedy of the Fall, in such a way as almost to absolve Adam of any guilt. Some midrashim attribute guilt to Adam for the Fall, mitigating somewhat indirectly Eve's guilt, but they do not exonerate Eve of seduction. On the other hand, we encounter highly laudatory midrashim on women's exceptional significance for husbands and families. Summing up the diversity of the rabbinic writings on this topic, one obtains a composite picture of merit and flaws of the characters in the Creation and Fall narratives.

I shall cite in paraphrased form some excerpts from Gen. Rab. 17:8 that brazenly accuse the woman of having brought death to the world, without indicating the source of this allegation: The woman's head is covered because she, who transgressed God's command, is ashamed to show herself in public. The women go before the bier of the deceased at a funeral because they caused death to come to the world. The precept of menstruation was given to the woman because she spilled Adam's blood. The precept of lighting the Sabbath candle was given to her because she extinguished Adam the First's soul.

While it is obvious that the midrash refers to the biblical narrative in Gen 3, we do not encounter any interpretation of the narrative to support such a conclusion; it probably relies on Adam's excuse to God that the woman gave him the fruit and he ate. This conclusion is reached, however, without analyzing the entire unfolding of the event as was done in sections 2.2.1 and 2.2.2, an endeavour which would have indicated Adam's main guilt. I hypothesize that the rabbis were probably aware that Adam's accusation of Eve, in reality his excuse, is not sufficient to attribute to her the entire guilt. Even at first sight it is obvious that God does not accept Adam's excuse, since he punishes him more severely than Eve, ${ }^{109}$ and in particular the rabbis could not have overlooked the fact that the first announcement of human death in Gen 3:19, a significant element in God's verdict and punishment, is addressed to Adam, in masculine, singular mode, not to Eve, since she was not created of earth.

Hence, the rabbinic accusation that the woman, and she alone, caused humanity's calamities and the advent of death — at variance with Scripture's unbiased reading of the biblical narrative-must be due to deeply ingrained preconceived ideas, plausibly as a result of Hellenistic influence. ${ }^{110}$ Moreover,

109 See the midrash of Gen. Rab. parsha 97:3 on this issue on p. 57. Bal, "Sexuality," 37 states: "Jahweh is clearly more severe on the man than on the woman. He explicitly blames him, and indirectly curses him by cursing the earth from which he was taken and to which he shall return."

110 Westermann, Genesis 1-11, at 235 expresses a similar conclusion regarding "a very traditional Christian conception of the story of the 'fall.' It is a telling example of how fixed and firm ideas can influence the understanding of the text." 
this accusation served as an aetiological justification of the existing social circumstances. ${ }^{111} \mathrm{Gen}$. Rab. parsha 18:2, cited in Chapter 1, declares that the divine effort to create a chaste woman remained unsuccessful, and that the woman bears all the defects God attempted to avoid. In this instance too, the midrash does not divulge its source and how this stipulation of the woman's immoral character was attained. However, on the basis of this allegation, the woman's guilt for the events at the Fall and its severe aftermath seems logical, without any further justification or textual support. Thus, one conjecture supports the other in a circular argument.

The woman, blamed for immoral character and for being guilty for humanity's calamities, can now be defamed for other alleged deficiencies. In the same midrash we read (paraphrased): The woman needs to perfume herself because the man was created from earth, which never stinks, and Eve was created from a bone; leaving meat without salt for three days, it will immediately smell bad. The woman's voice is high-pitched because, if you fill a pot with meat, there will be no noise moving it, but putting a bone in a pot, it will create a noise. The woman is not easily reconciled because the man was created from earth, and putting a drop of water upon it softens, but Eve was created from bone, and that will not soften even when soaked for some days.

A segment of a midrash in Abot R. Nat. Recension b, Chapter 1 accuses Eve of a brazen act of cheating. It says: as soon as Adam ate the forbidden fruit, given him by Eve without making him aware of its origin, his eyes spread apart (something most unpleasant) and his teeth in his mouth became numb; he asked her whether she fed him the fruit God commanded her not to eat. He said to her: just as my teeth became numb as a result of eating the prohibited fruit, so the teeth of all creatures should become numb. On the other hand, though this relieves Adam from any guilt in the Fall event, it does not put him in a good light either; cursing all humanity, his own offspring, for an evil deed performed by Eve against him.

111 Judith Hauptman, "Women and Jewish Law," in Women and Judaism, New Insights and Scholarship (ed. Frederick E. Greenspahn; New York: New York University Press, 2009) 64-87 at 67 writes: "Perhaps the Bible did not produce the patriarchal system but rather reflected gender relations in ancient society, such as those we find in the Code of Hammurabi." Lori Lefkovitz, In Scripture: The First Stories of Jewish Sexual Identities (Lanham, MD: Rowman \& Littlefield Publishers, 2010), at 14 writes that the first stories of the Hebrew Bible aim to "tell us not only how things came to be as they are, but why they must be as they are; they at once account for and regulate the present." 


\subsubsection{Midrashim Attributing Guilt to Adam, Mitigating Eve's Guilt}

As already stated, I have not come across a midrash explicitly accusing Adam of causing the events of the Fall; I shall now explain the motivation behind the use of the restrictive term "explicit." A remarkable midrash in Num. R. 12:3 states that a man's pride humiliates him (Prov 29:23), which refers to Adam; when he ate from the prohibited tree, God asked him to repent and return to the Garden, but Adam declined, and the Lord God said, The man has now become like one of us (Gen 3:22). The term "now," the midrash argues, means that God told Adam: even now repent and I will receive you.

To accuse Adam of such dreadful behaviour, acting defiantly against the Deity, seems unexpected, to say the least. I have not encountered any other midrash portraying Adam the First as so profoundly wicked; this seems to be the only one. I would hypothesize that emphasizing Adam's wickedness was not the author's intent; I would rather conjecture that he intended to demonstrate God's surpassing mercy in opposition to man's stubbornness. The inclusion of this detail may also point to the possibility that the author wished to indicate that man deliberately preferred living a civilized life with all its toils, tribulations, woes, challenges, and adversities, rather than a carefree natural life, like animals in the Garden of Eden. ${ }^{112}$ Whereas God's mercy is a recurring implicit motif in Scripture, we do not encounter any such hint regarding humanity's preference for civilization; its appearance in this midrash may indicate a familiarity of the author with Mesopotamian mythologies or the development of a more modern style of thinking in Jewish intellectual society. On the other hand, we encounter a somewhat similar narrative in the Quran Al-A'raf, Chapter 7:23 recording that Adam and Eve recognized their sin and asked God for forgiveness. In contrast to the midrash, which associates forgiveness with the returning of Adam and Eve to the Garden, the Quran narrative records their plea for forgiveness of their sin, without asking to return to the Garden. They said: "Our Lord we have wronged our own souls and if You forgive us not and bestow not upon us Your Mercy, we shall certainly be lost." We are unaware whether Muhammad intentionally reworked some details of the biblical story familiar to him, to distinguish his version from the Jewish narrative, or whether the Fall narrative, as we may plausibly assume, circulated in the Near East area in various versions and he chose the one that circulated in his environment. According to the Quran narrative, Adam and Eve were equally guilty for transgressing the divine command not to eat of the forbidden fruit, and consequently were punished equally by their expulsion from the Garden. In the above midrash Adam's guilt is explicitly emphasized to its utmost, but

112 See, by analogy, the Mesopotamian narrative of Gilgamesh and Enkidu. 
we encounter also in other midrashim Adam's implied guilt in the Fall event in different forms.

As mentioned earlier, the above midrash would greatly attenuate Eve's responsibility, at least for the expulsion from the Garden and its consequences for humanity's calamities; her alleged crime in "seducing" Adam to eat the forbidden fruit would have remained without any practical repercussion if Adam had agreed to repent. Another midrash attributes some responsibility for the Fall event to Adam, thus reducing Eve's liability: Abot R. Nat. Recension a, Chapter 1 accuses Adam of having overstated the divine command in his admonition to Eve, prohibiting what is permitted, lest she transgress what was prohibited. God commanded him not to eat from the tree of the knowledge of good and evil (Gen 2:17), but he added the prohibition against even touching it, as she said to the serpent (Gen 3:3). This offered the serpent an opportunity to lead Eve astray; he stood up, touched the tree with his hands and legs, and shook it until its fruits fell, demonstrating to her that nothing happened to him. Midrash Ps. 1, in a similar narrative, asserts that the serpent pushed Eve onto the tree, and yet she did not die. Thus, by his overzealous conduct Adam indirectly precipitated Eve's transgression.

Midrash Tehilim (Buber), Song 1 goes a step further in attesting to the shrewd stratagems employed by the serpent in convincing the woman to eat the fruit. We read there that the serpent said to her: "From this tree ate our Creator and created the world and all that it comprises, and if you eat from it, you could create a world like he did, as is written: you will be like God (Gen 3:5)." Such midrashim mitigate the woman's guilt, and indirectly attribute some guilt to Adam, who did not transmit to Eve God's exact command, thereby facilitating the serpent's strategy of arousing suspicion in Eve's mind about the truth of Adam's words to her. Scripture does not divulge whether Adam indeed did not accurately transmit God's command to Eve, as asserted in the above midrash, or whether Eve distorted Adam's words in repeating them to the serpent. The rabbis evidently chose the first contingency, which will permit conjecture, later in this chapter, about the philosophy underlying their overall approach to women.

Adam's guilt is also noticeable in some midrashim that use the derogatory term סרח in their description of Adam's conduct. The root of this term indicates "decay/bad smell," and in context it implies "having acted offensively/ having done mischief." For example, b. Hag. 12a claims that when God created Adam, his height reached from the earth to the sky, but when he acted offensively, God put his hand upon him and reduced his height to the current size. Amongst other midrashim, we encounter some that denigrate Adam more severely and others that portray him in a better light. For example, in 
b. Sanh. $38 \mathrm{~b}$ he is accused of being a heretic, while Gen. Rab. 19 implies that by defending his wicked deed, he accuses the woman that God gave him (Gen 3:12), showing contempt for God and committing blasphemy. In another midrash on Gen 2:20 (cited in Chapter 1 p. 27), he is perceived as grumbling or being ungrateful; first he complained of not having a mate, and now blames God for procuring him a mate.

On the other hand, we read in b. Erub. 18b: "Adam the First was a great righteous person, when he realized that the punishment of death came [to the world] [as a result] of him [his $\sin$ ], he fasted one hundred and thirty years and avoided sexual intercourse with his wife one hundred and thirty years and covered himself with fig foliage for one hundred and thirty years."

There is, however, one common denominator to all these midrashim, namely Adam's sin. God did not accept his excuse that the woman gave him the fruit; he ate the fruit, and is guilty of transgressing the divine command not to eat it. As we have seen, Scripture does not accuse the woman of anything, ${ }^{113}$ but the rabbis seem to accuse her of seducing Adam to eat the forbidden fruit. Hence, the two individuals involved are each accused of a different misdemeanour: Adam is accused of the transgression of God's command, and Eve for her seduction that led to it. ${ }^{114}$ However, the accusation against Eve of having instigated Adam's sin did not attenuate his guilt, since according to rabbinic law only the active perpetrator is liable for punishment, not the instigator (see the relevant citation of $b$. Qidd. $42 \mathrm{~b}$ on p. 59). This may be the motive prompting the rabbinic midrashim to denigrate women for their wicked character, deduced indirectly from the biblical narrative, without accusing the first woman of transgressions of divine commands.

Such a division of guilt by the rabbis allows us to draw the conclusion that the different degrees of Adam's guilt in the apparently contrasting midrashim should be perceived as still being within a wide boundary of rabbinic opinions and utterances, and thus not affecting the prevailing overall conception of Adam's guilt. Conversely, the many favourable midrashim about women refer to their vital purpose and function in society, but do not lessen their guilt for the instigation of the Fall and its consequences; likewise, they do not change the ingrained conviction of women's seductive character, although there is no support in biblical texts for such an insinuation. As we have seen, there is not

113 See my interpretation of Gen 3:13 on pp. $5^{1-52 .}$

114 Jubilees accuses both Adam and Eve of having eaten the forbidden fruit. We read in Jub. 3:24: "because she hearkened to the voice of the serpent, and did eat," and 3:25: "Because thou hast hearkened unto the voice of thy wife, and hast eaten of the tree of which I commanded thee that thou shouldst not eat thereof." 
the slightest hint in the Fall narrative about any calculated effort on Eve's part to convince Adam to eat the forbidden fruit.

\subsubsection{Rabbinic Attitudes towards Women: A Brief Overview}

The limited but representative collection of rabbinic midrashim expounded above exhibits a wide range of nuances regarding the respective responsibilities of Adam and Eve in the episode of the Fall. They vary from attributing the utmost guilt to Eve to a drastic mitigation of her liability, and likewise with respect to Adam's guilt. Summing up, however, Adam remains guilty for having transgressed God's command by consummating the forbidden fruit, and Eve is seen as guilty on account of her seductive influence on Adam, which prompted him to perform the sinful act; thus she is the initiating agent of the Fall calamity. On the other hand, superlative rabbinic aphorisms have been cited lauding women's indispensable function in the bosom of the family and society. Hence, we observe a composite picture of goodness and wickedness of the first man and woman in the Creation and Fall narratives, ${ }^{115}$ having a lasting impact on men and women according to the rabbinic belief that everything is written in the Torah, ${ }^{116}$ the divine blueprint for the creation of the world. ${ }^{117}$ Evidently, the midrashim associated with the Creation and Fall narratives and their protagonists Adam and Eve were built on a well-defined underlying philosophy/theology, regardless of whether it was the result of the contemporaneous circumstances and served as aetiological justification for ingrained attitudes and customs, or on the other hand for pragmatic motives, portraying women as dangerous temptresses as a way of avoiding sexual misdoings in Jewish society as a result of the male inclination towards promiscuity. The citation in the next section of their halakhot and quasi-halakhic instructions about the relationship between men and women, in addition to the midrashim already

115 For further citations of midrashim about women, see Ilan, Jewish Women; Judith R. Baskin, Midrashic Women: Formations of the Feminine in Rabbinic Literature (Hanover: Brandeis University Press, 2002); idem "Rabbinic Judaism and the Creation of Woman," in Judaism Since Gender (ed. Miriam Peskowitz and Laura Levitt; New York: Routledge, 1997) 125-130; Leila Leah Bronner, From Eve to Esther: Rabbinic Reconstructions of Biblical Women (Louisville, KY: Westminster John Knox Press, 1994); Lacks, Women and Judaism; Shulamit Waller, Women and Womanhood in the Talmudic Narratives (Tel Aviv: Hakibbutz Hameuchad, 1993, Hebrew). They are mostly written by Jewish feminist scholars, usually critical of rabbinic attitudes towards women.

116 We read in $m$. Abot 5:22: (paraphrased): Delve deeply into the Torah's contents, because it contains everything.

117 We read in m. Abot 3:14 that God has shown much affection to the Israelites by giving them the Torah, on the basis of which the world was created. 
discussed, will offer us a better perspective for revealing the general philosophy underlying the rabbinic literature on gender issues. I shall cite at this stage mainly the quasi-halakhic rabbinic instructions for behaviour between men and women; the legal ramifications of women's status, and the consequent halakhot, will be discussed in Part 2 of the book. At this juncture I would like only to mention that the rabbis established many rules for the enhancement of women's rights within the constraint of their being under the authority of their fathers and husbands.

\subsubsection{Rabbinic Rules of Behaviour for Contact with Women and Their Interpretation}

We read in $m$. Qidd. 2:12: "A man must not be alone [in a secluded place] with two women, but one woman may be alone with two men; Rabbi Simeon says: 'Even one man may stay in a secluded place with two women if his wife is with him, and he may sleep with them in one lodging house, because his wife keeps him under her surveillance." B. Qidd. 8ob explains the motive for the discrimination: "because women are frivolous [therefore even two women would not be ashamed to have sexual intercourse with one man]." It is obvious that these and similar rules of behaviour-I doubt whether one can call them halakhot - are instituted in order to avoid sexual misbehaviour in the frame of the general rabbinic system of establishing preventive rules prohibiting legally permitted acts that may lead to legally prohibited acts. The mishnah and the deliberations about it in the Gemara are not precisely defined and are open to many interpretations. The mishnah does not indicate whether the rule applies to unwed women, with whom even sexual intercourse would not be prohibited according to Scripture (Exod 22:15 indicates the legal consequences of a seducing act), or whether it applies only to married women or to those with whom sexual intercourse is forbidden, with whom indeed intercourse would be a capital offence. The Gemara does not elucidate this issue; only the commentators declare that the rabbinic rule applies also to unwed women. ${ }^{118}$

What interests us at this juncture is mainly the motive of the prohibition, that is, who is assumed to be the initiator of the mischief, the man or the woman, and the reason behind the difference between the seclusion of one man with two women or one woman with two men. Pursuing Rabbi Simeon's assertion in the second part of the mishnah that his wife will keep an eye on him and will prevent debauchery, it becomes evident that it is the man who is

118 Later commentators (Rashi does not relate to this issue) follow Maimonides, who maintains that it is a tradition, that is, he does not attempt to reveal midrashic support for it; he conjectures that it was instituted after Amnon's rape of Tamar (2 Sam 13). 
distrusted and suspected of attempting to seduce the women. The reason for the difference in the surmised behaviour of one man and two women and its opposite, explained in the Gemara as being "because women are frivolous," as I translated above, is the common interpretation of this vague phrase, seeming to suspect the women of immorality, yet it may be interpreted differently. ${ }^{119} \mathrm{In}$ fact, in b. Pesah. 88b we encounter an aphorism: מלכה ומלך דדעתן קלה עליהן, which we should interpret in the context as "A queen and a king who don't care." As would also seem to follow from scrutiny of such expressions in other later writings, the expression should be interpreted as characterising people without the faculty of deep or profound thinking and consequently more susceptible to seduction, or "lightheaded" as Ilan translates it. ${ }^{120}$ In the case of the two women, Rashi confuses us, offering, in my opinion, two different explanations. He asserts: "and both are easily seduced," reflecting a tender and docile nature, but then adds, "one will not be afraid of her female companion, who will do the same [letting herself to be seduced]." In the case of two men, in contrast, Rashi explains that a man would be ashamed to lie with a woman in another man's presence, and therefore one woman is permitted to be secluded with two men. ${ }^{121}$ The second motive does not seem favourable to women. At any rate, it is evident that however we interpret the rabbinic assumption about women's character, it is the men, not the women, who are suspected to initiate and be the active element of the sexual mischief. ${ }^{122}$ One cannot compare this

\footnotetext{
119 The different versions of the phrase in b. Qidd. hint at the distinct presumed meanings of the ancient copyists.

120 Ilan, Jewish Women, 199.

121 Later in the discussion in b. Qidd. 8ob, Rav Judah limits the permission for a woman to be secluded with two men to the case when they are known to be moral, but if they are immoral a woman is prohibited to remain secluded even with ten such men.

122 I disagree with Judith Romney Wegner, The Status of Women in the Mishnah (New York: Oxford University Press, 1988), who at 159 interprets the mishnah's motive as being because "women are prone to moral laxity and cannot be trusted to behave themselves," and at 160 states, "The sages pin most of the blame for sexual lapses on women." Wegner perceives the mishnah as strongly prejudiced against women from all aspects. I believe that an unbiased perception of the mishnah leads to a more objective apprehension of the rabbinic approach towards women. On the other hand, Judith Hauptman, Rereading the Rabbis, A Woman's Voice (Boulder, co: Westview Press, 1998) seems to agree with my understanding of the rabbinic attitude. On the same topic, but on the text of another mishnah, at 48 she states: "this material does not imply that men fall prey to their sexual urges because women deliberately excite them."
} 
situation to the events of the Fall narrative, in which the woman is accused by the rabbis of being the seductress. ${ }^{123}$

A number of similar admonitions and aphorisms, such as in b. Erub. 18b, $m$. Abot 1:5, and b. Ned. 20a, counsel men to avoid unnecessary contact with women and avoid gazing at them, and thus demonstrate the danger inherent in approaching a woman, but there is no hint of accusation against the woman for seducing the man; rather, the opposite. The man is suspected of seducing the woman, and she may yield to the man's aggressive approach, being of a tender personality and not strong enough to prevail against it; for this reason, a woman is a dangerous person, and a man should keep his distance from her. ${ }^{124}$

\subsection{Underlying Philosophy and Theology of Rabbinic Midrashim and Quasi-Halakhot}

\subsubsection{Women's Character: The Dinah Affair}

It is my hypothesis that the rabbis, being pragmatic, were induced to reach such a conclusion about woman's character by practical considerations: portraying woman as a dangerous person, either as easily seduced as in the instructions just discussed or as a temptress like Eve her ancestor, was a key tactic in rabbinic attempts to avert sexual misdoings resulting from men's inclination towards promiscuity, spurred on by the unruly male libido. ${ }^{125}$ The burden of man's continence was shifted to woman by means of her portrayal as a source of danger. ${ }^{126}$ In order to substantiate this postulate, I shall quote rabbinic

123 Roth, "Gender and Law," 179, commenting on a court case from ancient Mesopotamia against a woman accused of collusion with the murderers of her husband, assumes that her conviction for murder, although she did not participate in the slaying, was motivated by the dominant perception that "women are more easily intimidated," and because a woman is "presumed a seductress," at 180. These two apparently opposed traits were fused together, thus creating a stereotype of woman's wickedness.

124 Y. Sotah 7:1, 21b insinuates that God did not speak to any woman except Sarah, thus justifying the rabbinic maxim not to talk too much with women.

125 Judith Hauptman, "Feminist Perspectives on Rabbinic Texts," in Feminist Perspectives on Jewish Studies (ed. Lynn Davidman and Shelly Tenenbaum; New Haven, ст:Yale University Press, 1994) 40-61, at 45 writes: "a careful reading of the Mishnah [m. Qidd. 2:12] suggests that it is the men's sexuality — that is, men's easily aroused and then hard to control sexual lust - that lies, not below, but on the surface of some of the mishnah's statements, such as those concerning the segregation of the sexes in semi-private settings."

126 The rabbis were well aware that the restrictions they imposed on women's outdoor appearance and behaviour in public have no root in Scripture. M. Ket. 7:6 enumerates 
midrashim about Dinah, claiming that her unchaste behaviour was the cause of her calamity; hence, woman is blamed as the cause of man's sexual misdeeds. We read in Gen. Rab. parsha 8: "[A woman should not go out to public places because she will ultimately stumble into fornication, as happened to Dinah; she went out (ותצא) and in the end she failed."127

Abot R. Nat. Recension b, Chapter 3 offers a different aspect of her guilt, suggesting that Eccl 10:8, "Whoever digs a pit may fall into it; whoever breaks through a wall may be bitten by a snake," refers to Dinah. Whilst her brothers were studying Scripture, she went out to meet the local girls (a frivolous act in comparison) and was bitten by Shechem, the snake. ${ }^{128} \mathrm{Gen}$. Rab. 8 o goes a step further, implying that Dinah showed a tempting posture, exhibiting her bare arm. ${ }^{129}$ The rabbis allege Dinah's improper behaviour as the cause of her calamity, rather than attributing it to Shechem's sexual drive, incited by a girl from a different race and complexion and probably extremely beautiful, being a sister of Joseph, who was "well built and handsome" (Gen 39:6). Just as Joseph attracted Potiphar's wife through his beauty, we may assume Shechem was attracted to Dinah, his sister. ${ }^{130}$ Hence Shechem's attraction to Dinah, Joseph's sister, would be a plausible explanation for the incident, "particularly in view

"immoral" acts, such as going out in public with an uncovered head, spinning in the market, and speaking with any man, as transgressions of Jewish customs, in contrast to other transgressions quoted as contraventions of biblical decrees.

127 The deduction made from the narrative indicates the real motive of the midrash, to promote chastity by preventing women from intermingling with men.

128 It is remarkable that a nineteenth-century German scholar, Friedrich W. Schröder, in Erste Buch Moses at 530 makes a similar accusation against Dinah, referring to the text of Tit 2:5. Text copied from Suzanne Scholz, "Through Whose Eyes? A 'Right' Reading of Genesis 34," in The Feminist Companion to the Bible (2nd ser.; ed. Athalya Brenner; Sheffield: Sheffield Academic Press, 1998) 150-71 at 156. We read there: "Dinah is dishonoured violently because she roams about more freely than she should, leaving her father's house. She should have stayed at home, as the apostle orders (Tit 2:5) and nature recommends, because virgins, like wives, should be keeper of the house." Although I doubt that Schröder had any notion of these midrashim, he pronounces the same accusation as the rabbis, almost verbatim, based on Titus.

129 We read in Gen. Rab. parsha 80:5: "he [Shechem son of Hamor] saw her bare arm [and that caused his excitement and the rape]."

130 Various midrashim exalt Joseph's beauty. B. Sotah 13b claims that Potiphar bought Joseph for his paedophile use, but was castrated by an angel. Midrash Tanhuma, parsha Wayeshev records that Potiphar's wife presented Joseph to her women friends to demonstrate to them the tension she experienced continuously because of his beauty and her desire to lie with him. 
of Gen 34:3, 'His heart was drawn to Dinah daughter of Jacob,' " but the rabbis asserted that her immoral attire was the cause.

Gen Rab. 80:1 even attributes Dinah's rape in part to unchaste behaviour prompted by an evil genealogical trait inherited from her mother, Leah, who allegedly adorned herself like a prostitute to lure Jacob to sleep with her (Gen 30:16).

\subsubsection{Frymer-Kensky's Theory}

Frymer-Kensky, ${ }^{131}$ referring to Rashi's calumniation of Dinah and the Christian tradition of vilifying women who "go out," seems to presume that Scripture indeed intended this interpretation of its phrase ותצא דינה. In my opinion, I do not think that the redactor of the narrative in Gen 34 intended to blame Dinah's (or Jacob's) failure "to control her sexuality" for her calamity, as Frymer-Kensky argues; ${ }^{132}$ the fact that Dinah had gone out is simply an essential and inevitable element of the story, portraying the circumstances of the event. There is no evil denotation in Scripture of a woman who went out alone without the guardianship of her father, brothers, or husband. Rebekah went to inquire to the Lord, probably to a sanctuary (Gen 25:22), and Moses' sister watched his basket in the Nile and went to call his mother (Exod 2:4 and 8), without any guardian; the term ותלך "and she went" is used in both verses. Whatever is meant by the redactor's assertion that her brothers were furious, "because Shechem has done a disgraceful thing in Israel by lying with Jacob's daughter - a thing that should not be done" (Gen 34:7) - plausibly breaking the conventional custom to ask the father for the hand of his daughter, before approaching her-what is crucial for understanding the motive for their indignation is their defence against Jacob's accusation (Gen 34: 31). ${ }^{133}$ They defended Dinah's honour, but did not accuse her of unchaste behaviour, nor did they plead to have defended the honour of the family for failing "Israel's attitude towards the chastity and virginity of daughters." 134 Frymer-Kensky, relying on cross-cultural influences, perceives the core of the Dinah narrative and its outgrowth, as well as the

\footnotetext{
131 Tikva Frymer-Kensky, "Virginity in the Bible," in Gender and Law in the Hebrew Bible and the Ancient Near East (ed. Bernard M. Levinson et al.; Sheffield: Sheffield Academic Press, 1998) $79-96$, at 86.

132 Ibid., 90.

133 Tzemah Yoreh, "Shekhem and the So-called Rape of Dinah," in Vixens Disturbing Vineyards (ed. Tzemah Yoreh et al.) $67-78$, analyses the narrative in terms of a number of different sources, and asserts at 77 that the final redactor "felt the need to edit the story and preserve the moral fabric of Israel's progenitors," and therefore painted Shechem in a negative light by adding details absent in the original story.

134 Ibid., 78.
} 
relevant biblical rules for the seducer, rapist, and slanderer, as the consequence of the transgressor's act "for the dishonor of the family for failing to control and protect their women."135 The stoning of the fornicating girl at the door of her father's house (Deut 22:21) does not point to his failure; Scripture emphasizes that something evil was done in Israel, not by her family. Therefore, the townspeople, representing Israel, stone her; it is done at her father's house, because that was where she had performed her disgraceful acts, as the text emphasizes. ${ }^{136}$ We encounter a similar reaction to the rape of the concubine in Judges; the phrase נבלה בישראל "disgraceful act in Israel” appears in Judg 20:6 and 10, as in our case. There, too, it provoked the military intervention of all Israel. Only the priest's daughter is said to have disgraced her father, but this has no association with his failing to control his daughter's sexuality; priests lie under different codices and requirements, and moreover the priest's daughter is burned, not stoned, a fact indicating a clear distinction between the two occurrences. ${ }^{137}$ This incident therefore cannot serve as evidence for FrymerKensky's claim.

It cannot be denied that in the prehistoric period of the Israelite tribes, the family defended their honour by hostile acts when disgraced by a daughter's actions, but Scripture has changed, in a precise manner, the intrinsic theology of the prevailing customs and laws and often their exterior pattern as well, before absorbing and assimilating them into Israelite mythology and law. Some of the motives and mythologies of these prehistoric customs, shared with neighbouring cultures, fell into oblivion or were discarded altogether; we still find traces of others in Scripture, as for example the ancient agricultural aspect of the Passover and Feast of the Booths, which later acquired new motivations and customs.

The same process occurred regarding many scriptural laws. Scripture created two great classes of transgressions: those that affected damage to persons, in modern legal jargon civil issues, and those that were deemed an affront to the divine established order in defiance of God's authority, which we would now call criminal law; seducing or raping an unbetrothed girl is not an offence against the divine order, according to Israelite law. Frymer-Kensky writes: "an unmarried girl's consent [in a seduction] does not make the sex a permissible

\footnotetext{
135 Frymer-Kensky, 90-91.

136 Deut 22:21: "She shall be brought to the door of her father's house and there the men of her town shall stone her to death. She has done an outrageous thing in Israel by being promiscuous while still in her father's house" (NIV).

137 Lev 21:9: "If a priest's daughter defiles herself by becoming a prostitute, she disgraces her father; she must be burned in the fire."
} 
act,"138 but neither does it make it a prohibited criminal act. In fact, at the cases of adultery in Deut 22, we find the formulas ובערת הרע מקרבך "You must purge the evil from among you" or מישראל from Israel. At Deut 22:28-29, however, whether it is understood to refer to an act of seduction or a rape, this phrase is not mentioned; the wrongful act is settled by pecuniary compensation, like a theft or the infliction of bodily damages, as recorded in Exod 21. While it may not be considered a moral act, ${ }^{139}$ there is no other sanction provided in Scripture beyond the redressing of the damage, by marrying her, with or without the possibility of ever divorcing her, paying the bride price (Exod 22:16), or both (Deut 22:29); or in some cases, a fine for a theft or robbery (Exod 21:37 and 22:3; Lev 5:21-23) is imposed. ${ }^{140}$ Only when the loss of life or sexual misdeeds prohibited by the divine law are involved does the act become a transgression against the Deity's law, a criminal offence that goes beyond a settlement between the injured and the injuring party, as was the rule in Mesopotamian ancient law, ${ }^{141}$ and becomes an issue between God and the criminal. Humans convict him and perform the execution, but they have no authority to change the verdict established by God, to substitute the capital punishment by

138 Frymer-Kensky, "Virginity," 87.

139 The traditional commentator Ramban explains the intent of the phrase קדשים תהיו holy": Scripture prohibited illicit sexual intercourse and the consumption of forbidden food, but permitted sexual intercourse with one's wife and the consumption of meat and wine; hence the lustful man could be engaged in lascivious sexual activity with his wife or many wives, the glutton in guzzling meat and wine, and the intemperate man in uttering obscenities, because all these deeds are not prohibited in the Torah. He would be a villain, but his actions would not be forbidden in Scripture, and therefore the mandate "Be holy" is given, meaning to abstain from such behaviour. Ramban is the only commentator of whom I know who alleges that gluttony and excessive sexual activity are implicitly prohibited by Scripture. We do not encounter any limitations on legitimate sex in Scripture, and the Torah explicitly permits eating as much meat as one desires (Deut 12:20b and 21b).

140 It is not within the scope of this book to consider the rabbinic justifications for the differences of these fines, indicated in Scripture for the different acts and circumstances. I would hypothesize that these differences flow from the economic conditions and the loss of the injured party for the period during which the use of the stolen animal or object could not be enjoyed.

141 In Middle Assyrian Law, MAL A $₫ 10$ condemns a murderer to capital punishment, identical to the scriptural law, but allows the injured party to agree to an accommodation, thus averting execution. MAL A $\mid 15$ and the Code of Hammurabi §127 likewise condemn the adulterer and the adulteress to capital punishment, exactly as in Scripture, but the injured party, her husband, can agree to a lesser punishment or can altogether forgive his wife, although in this case he must do the same for the male adulterer. The above data are sourced from Roth, Law Collections. 
payment of a ransom (Num 35:31) or to forgive the transgressor altogether (Num 22:22), as in Mesopotamian law. ${ }^{142}$ The Mesopotamian codices may have been the source of the biblical law convicting the transgressors of these rules to capital punishment, but Scripture abolished the potential to substitute them with pecuniary compensation, to change their severe character or to annul them altogether by forgiveness. There is no "crime of honour" in Israel, as Frymer-Kensky claims; ${ }^{143}$ there are only the two cited categories, and their boundaries are well defined, unalterable, and eternally valid.

We should be careful not to impose on Scripture later interpretations of biblical laws and lore by the rabbis and by Christian theologians, presuming in doing so that such interpretations constituted the intent of the original author/ redactor. ${ }^{144}$ We must disregard our cultural background, acquired from different sources, and discern between what we think today and the plain meaning of the scriptural text. The arguments and evidence of this section indicate the flaws inherent in reading our contemporary thoughts and knowledge into biblical texts.

\subsubsection{Rabbinic Conceptions of Men's Character}

Until now, I have discussed rabbinic opinions about women; now, suggesting that these were strongly influenced by their conception about the character of men, we shall cite some of their pronouncements on this topic. The rabbinic instructions to men to avoid contact with women, cited above, indicate that their motive was the apprehension that men would not be able to control their libidos at encounters with women. ${ }^{145} \mathrm{~B}$. Qidd. $29 \mathrm{~b}$ states that an unmarried man over twenty lives all his days with sinful thoughts. Until a man reaches the age of twenty God waits patiently to see him married, but if he does not marry at that stage, God curses him. Therefore, b. Yeb. 61b asserts that a man should have a wife even if he has accomplished his duty of procreation, as God said: "It is not good for the man to be alone'" (Gen 2:18). Their lack of confidence

142 See Paul Heger, "Source of Law in the Biblical and Mesopotamian Law Collection," in Biblica Vol. 86, Fasc. 3, (2006) 324-342.

143 Roth, Law Collections, 83.

144 In a recent article, Susannah Heschel, "The Religious Issue, Religion and Its Discontents," AJS Perspectives: The Magazine of the Association for Jewish Studies (Fall 2011) 6-7, at 6 discusses a related issue: "Pervasive in the field of religion is a confusion of religion and Christianity, and far too close an alliance between Protestant interests and the scholarly study of religion."

145 Hauptman, "Women and Jewish Law," at 69 writes: "a close reading of the mishnaic texts suggests that it was men's unruly sexual potential, not women's that led to the segregation of the sexes." 
in man's ability to contain his libido also affects the priests, and even requires deviations from biblical regulations.

M. Sotah 1:5 decrees that if the Unfaithful Wife is attractive or has nice hair, the priest does not tear her garments by grasping her forcefully and does not loosen her hair, ${ }^{146}$ actions stipulated in Scripture to disgrace her. The suspicion that the onlookers (the young priests) would be sexually aroused, and try all her life to find her and lie with her, is indicated as the motive of this rule. An alternative motive is the possibility that being sexually aroused, they might masturbate, a severe sin. M. Sotah 1:3b distrusts even the suspicious husband, conjecturing that he might lie with his wife on the way to the priest for the procedure of the ordeal; therefore, the Court nominates two scholars to accompany them to avoid such a possibility.

The rabbis, aware of the strength of the male libido, attempted by all means to avoid its generating sinful deeds. They even suspected that men would attempt stratagems in order to look at women, such as giving coins to a woman in order to look at her or following a woman crossing a river in order to see her bare flesh (b. Erub. 18b). They were not afraid that the women would seduce the men, but that the men in their excitement would seduce the women, as we see from the following midrash in Gen. Rab. 17:8 (paraphrased): The man courts the woman [not the other way around] because he searches to recover the rib he lost, but the lost item [the woman] does not search for its owner. Some rabbis had an even worse opinion about men's sexual "perverseness," and were aware of their inability to dissuade them from following their excessive and obscene lust except by frightening them with the severe punishment of their offspring, as cited below.

B. Ned. 20a quotes Rabbi Johanan ben Dahbai (paraphrased): Angels told me four things: children are born lame because their fathers turned their table upwards (metaphoric) at intercourse; are born dumb because their fathers kissed the woman's sexual member; are born deaf because their fathers spoke erotically during intercourse; and born blind because their fathers gazed at their wife's sexual member. These presumed perverted manners do not constitute a theoretical pronouncement, but refer to real occurrences, as we learn from a narrative in $b$. Ned. $20 \mathrm{~b}$, recounting that when a woman complained to Rabbi that her husband overturned the regular method in their sexual intercourse, he said to her that he was sorry, but was unable to do anything, because

146 Num 5:18 uses the term פרע, meaning to uncover her hair, and $b$. Sotah 8a deduces by midrashic method that this term also includes the uncovering of her body (breast); from the same phrase it is also deduced that the priest uncovers her hair, which was habitually braided, and then loosens it. This action would reveal the full beauty of her hair. 
Scripture allows the man to have intercourse as he wishes. Rav, responding to a similar complaint, compared the man's prerogative to have intercourse in the way he pleases to his right to eat his fish cooked in the manner he desires. We observe that the rabbis may not have been pleased with such behaviour, ${ }^{147}$ and showed compassion to the women, but as it seems to me did not venture to change the prevailing custom for the pragmatic reason that such a change would not be enforceable, ${ }^{148}$ particularly since such behaviour is not prohibited in Scripture. And indeed, $b$. Ned. 20 b discards Rabbi Johanan ben Dahbai's dictum, ${ }^{149}$ and compares the man's privilege to perform sexual intercourse to his right to eat his food as he wishes. On the other hand, the rabbis granted the women the unrestrained right of pleasure from permitted forms of sexual intercourse on the basis of their desire for men, ${ }^{150}$ implanted in them by God (Gen 3: 16) and reconfirmed in Exod 21:10 as a legal right that husbands must grant them. ${ }^{151}$ We read in $b$. Ket. 48 a that the woman has the right to demand that both partners should be naked during sexual intercourse. ${ }^{152}$

However, the rabbis not only suspected the common people of possible sexual misbehaviour, but also believed learned sages were susceptible to immoral behaviour. B. Yeb. 63a tells a stimulating story: Although Rabbi Hiia's wife angered him, he bought her gifts when he found something suitable. To a rabbi, amazed by his conduct, he said: We should be satisfied with women's functions in raising our children and rescuing us from the sin of fornication. B. Yeb. $37 \mathrm{~b}$ records that two rabbis (each separately in different locations) invited women to marry them for the period of their sojourn in town. In reply to the argument that such behaviour conflicts with some halakhah, it is explained that the rabbis did not actually have intercourse with these temporary

147 See Ramban's opinion about the perception of holiness in n. 139, p. 96.

148 B. B. Bat. 6ob counsels against making decrees that the people are unlikely to follow.

149 In fact, Rabbi Johanan ben Dahbai did not pronounce his dictum as a halakhah, which would mean that such sexual practices were prohibited by Scripture or by a rabbinic rule; he used a metaphoric stratagem to influence his audience and to induce them to avoid such excessively lecherous sexual manners, lest they lead to a loss of restraint and thus to performing sinful acts.

150 We read further in $b$. Ned. 2ob: "Every man [who has sexual intercourse] requested by his wife [not by his initiative] has outstanding sons, of such excellence that were not even in Moses' generation."

$15^{1}$ We read there: "he must not deprive her food clothing and marital rights."

$15^{2}$ It is stressed there that if the husband insists on having sexual intercourse while dressed, his wife has the right to ask for a divorce, and he must pay her the ketubah, since he infringed on her right to full-fledged pleasure from sexual intercourse. 
wives; they just cohabitated with them. Having a woman at their disposition helped them to master their libido, as the renowned maxim declares: "There is no comparison between the emotion and behaviour of somebody who has a loaf of bread in his basket, and of the one who has not." This broad-minded metaphor supports the intensity of the rabbinic counsel to be married; a man who has a wife at his disposition is not so easily excited at seeing a woman as a man without one.

\subsection{Deducing the Theology and Philosophy Underlying Rabbinic Literature}

\subsubsection{General Principles, Criteria, and Premises}

Before considering the theology and philosophy behind the rabbis' varied and apparently contradictory midrashim and pronouncements revealing their attitude towards women, I would like to draw the attention of the reader to two principles important to keep in mind when attempting to derive philosophical reflections from their literature. It is absolutely imperative not to deduce general opinions and ideologies from a single midrash or assertion. Ancient authors such as the rabbis were not overly concerned with ideas that might transpire from their dicta, and as we have seen, some rabbinic assertions seem utterly to contradict others, ${ }^{153}$ and at times to conflict with undisputed and deeply

153 Gwynn Kessler, Conceiving Israel: The Fetus in Rabbinic Narrative (Philadelphia: University of Pennsylvania Press, 2009) offers a representative example of the extent of erroneous conclusions that may be reached, perhaps through imprudence or a conscious attempt to support a prejudiced opinion by an unwarranted deduction from a rabbinic midrash. Kessler argues that a midrash in Mek. Beshalah, Mass. D'shira 1, asserting that the fetuses in the womb of their mothers also participated in the songs and praise to God at the Crossing of the Sea, marginalized women; the fetuses, males in midrashic narratives, were active, but the women were only passive vessels in the procreative process. This, she claims, demonstrates the rabbinic negative attitude towards women. The midrash of the Mek., the basis of her theory, is one among several whose scope is to amplify the magnificence of the Israelites' song at the Crossing of the Sea, without any thoughts of an underlying philosophy regarding the significance of the fetuses or women. It is similar to a homily in Midrash Thehilim (Buber) 78, which inflates by midrashic methods the number of plagues the Egyptians suffered in Egypt (fifty) and at the Crossing of the Sea (two hundred and fifty). Both have no theological purpose, and cannot support theological deductions. Furthermore, Kessler ignores the midrash in the same Mek., parsha 3, exalting the participation of women at the miracle at the Sea. It asserts that even a maidservant saw at this event what the prophets Isaiah and Ezekiel did not see (Isa 6 and Ezek 1). Moreover, b.Yeb. 78a asserts (in contrast to qumranic halakhah) that the fetus is deemed 
ingrained theological principles. ${ }^{154}$ Therefore, one may attempt to draw comprehensive deductions only from a variety of rabbinic narratives, midrashim and utterances that allow a reflection from a broad view of contrasting assertions and that may lead to a plausible solution that reconciles among them. I believe that the varied selection of rabbinic midrashim quoted above offers us auspicious prospects for investigating the rabbis' underlying general philosophy with respect to their attitude towards women and the presumptive goal of their pronouncements and instructions. The second principle to keep in mind is my postulate that the rabbis were pragmatic lawgivers, who made their decisions on the basis of their conception of what would be necessary in order to attain the desired objectives, and at the same time what would be feasible: that is, appropriate for the prevailing circumstances and likely to be acknowledged and fulfilled by the people. The facts of life in their period stimulated the creation of suitable aetiological midrashim that served to ensure the stability of the social system, and probably also to demonstrate that all instructions necessary for life are written in the Torah in all its forms, written and oral. In what follows, I might also remark that reflections on the aim of the midrashim, intertextual sources, and rabbinic suggestions for correct behaviour in relationships with women assisted me in reaching my conclusions.

\subsubsection{Assessing Contrasting Midrashim and Pronouncements}

We read in Eccl. Rab. parsha 9: "Everyone who has no wife, lives without goodness, without helper, without joy, without blessing, without forgiveness [of sin]." B. B. Mez. 59a asserts that a woman brings wealth, as is written: "and he entreated Abram well for her sake of his wife" (Gen 12:16). ${ }^{155}$ B. Ber. $57 \mathrm{~b}$ emphasizes the happiness that a woman brings to a man, declaring that three

to be like the thigh of its mother from a legal perspective; hence, the fetus has no individual personality before being born, but is a member of the mother, contradicting Kessler's thesis that according to rabbinic theology the fetus is significant, not the mother. See Paul Heger, "Stringency in Qumran?" in JSJ 42 (2011) 1-30, particularly 6-10, for an extended discussion of this topic.

154 See, for example, the midrash in Gen R. 18 parsha 2 about the creation of the woman (pp. 42-43), which overlooks the fact that its contents implicitly contradict divine omnipotence and omniscience, by alleging that God did not succeed in accomplishing his creation of the woman as intended - a statement bordering on heresy.

155 The quotation of this verse to support the rabbinic maxim demonstrates the validity of the principle of not deducing philosophical reflections from one midrash, since the authors of the midrashim were not overly concerned with ideas that might transpire from their pronouncements. Evidently, the rabbis would have been embarrassed to reflect that in supporting their maxim by quoting Gen 12:16, they might be seen as recommending 
things gratify man, namely a refined dwelling, a beautiful woman, and neat objects. B. Sanh. 10ob declares that the husband of a beautiful wife is blessed and his lifespan is doubled. ${ }^{156}$ The highly slanderous midrash in Gen. Rab. parsha 18:2 quoted on pages 42-43 of Chapter 1 , is amply reversed by the great array of contrasting assertions, and should be discounted as an exaggerated assertion by one rabbi, plausibly without any afterthoughts concerning theological or halakhic deductions that might be derived from his midrash. An excellent example of an inversion of a deduction from the same subject offer us two midrashim explaining the reason for women's menstruation. We read above in Gen. Rab. 17:8 that menstruation was inflicted on women as penitence for Eve's spilling of Adam's blood. In b. Nid. 31b, however, menstruation and the seven days abstention from sex is presented as instituted for the benefit of the woman, to have her husband longing for his wife after a short separation. ${ }^{157}$

The significance of harmonious family life and its dependence on the husband's attitude towards his wife is manifest in $b$. Yeb. $62 \mathrm{~b}$, which says that if one loves one's wife like oneself, honours her more than oneself, and instructs one's sons and daughters to be righteous, getting them married close to puberty, Scripture says about him: "And thou shalt know that thy tent is in peace" (Job 5:24). B. Yeb. 63b states that a man does not attain comfort from other than his first wife, and when a man marries his sins are forgiven. B. Sanh. 22a declares that even the altar bursts into tears for one who divorces his first wife, and that every man whose first wife died hurts as though the Temple had been destroyed in his lifetime.

We have also observed from previous citations (Chapter 1, p. 23) the rabbinic opinions placing a high valuation of the woman's function and usefulness, as a helper and as a maidservant, and comparing her to gold. In their quest to ensure the stability of the institution of marriage, the rabbis did not retract their slanderous pronouncements on women's defects, but as we have seen, they stressed their indispensable function and benefit for man and family.

gaining wealth thanks to one's wife by emulating Abraham, who was recompensed by Pharaoh for the enjoyment Pharaoh had of Sarai.

${ }_{156}$ Siracides' assertion at 26:1, "Blessed is the man that hath a virtuous wife, for the number of his days shall be double," is noteworthy in this connection.

157 I disagree with Baskin, Midrashic Women, 23, who perceives the other side of the coin, arguing that this assertion is "'backhanded,' since it implies that a man in unremitting contact with his wife and her natural processes will soon find his spouse repugnant." I think that the term in the dictum in this context should be interpreted as "boring" rather than "repugnant," as Baskin alleges. The implied reason for the husband's lack of sexual desire seems to me to be hinting at boredom. 
They even emphasized the significance of arousing man's sexual desire by means of female beauty treatments. We read in b. Shab. 95a: God braided Eve's hair before bringing her to Adam. Abot R. Nat., Recension a, Chapter 4 claims that God adorned her like a bride. Cant. Rab. parsh 4 implicitly encourages the adornment of women for the enjoyment of their husbands, asking: "Whence did the daughters of Israel get adornments for their husbands' enjoyment during their dwelling in the desert?" There is no concern about seduction by beautifully adorned women. In $b$. Sabb. 64b, Rabbi Akiba permits menstruating women to adorn themselves, despite the possibility of arousing their husbands, leading to illegal intercourse, since prohibiting such adornment may make a wife repugnant to her husband and incite him to divorce her. ${ }^{158}$ And indeed the rabbinic halakha acknowledges Rabbi Akiba's opinion, granting priority to the preservation of the harmonious family life over the concern of a potential transgression of the law. Rabbi Akiba here puts the burden on the man, in contrast to more typical rabbinic rules criticizing immodest or shameless clothing and appearance in women and thus shifting the burden on the woman to be modestly dressed in order not to provoke the man's libido.

By midrashic methods, Abot R. Nat. Recension b, Chapter 45 deduces from biblical verses that men and women have the same typical faults, while Chapter 42 similarly claims that ten evil decrees were enacted on each of Adam, Eve, the serpent, and the earth. This midrash emphasizes the equal responsibility of Adam and Eve regarding the primeval sin and expulsion from the Garden, and seems to me significant for a deduction of the overall rabbinic attitude towards women. I should reiterate here, in closing these assessments, that they relate to the rabbinic stance regarding the character of woman, slandered by preconceived interpretation of the Fall narrative, but not to their legal status.

\subsubsection{Summarizing Rabbinic Opinion}

Founded on the consideration of the variety of rabbinic midrashim, pronouncements, and some halakhot instituted to enhance women's lot relative to the standards of the period, I came to the conclusion that the rabbis did not demonize women, as may seem to be the case based on some midrashim. Against those that portray women in a bad light there are others that praise women, extolling their outstanding importance for married life and their function in

$15^{8}$ See in m. Git. 9:10 Rabbi Akiba's opinion that a man may divorce his wife if he finds a prettier one. 
family and society. ${ }^{159}$ Both were the result of the rabbis' pragmatism. ${ }^{160}$ The vilification of women was an appropriate device to minimize the occurrence of sexual transgression by men in whom eros is powerful, and the laudatory assertions regarding women counterbalanced these in order to ensure the stability of family life.

Pronouncements such as those quoted above praising women cannot be reconciled with their demonization. The same applies to rabbinic halakhot, which may seem trivial, but in some instances constitute very important rules, absent in Scripture, as for example the rabbinic decree that at maturity a minor maidservant sold by her family (mother and brother) can abandon the man in question, without even a divorce. But even when sold by her father, she must agree finally to be married to her master or his son; in this case, however, she needs a formal divorce if she refuses to marry the master or his son, since her sale with the intent to be married is deemed equivalent to having been betrothed. ${ }^{161}$ There is no hint in Scripture that a girl can avert marriage to her master; Exod 21:8-11 grants this right only to the master. The rabbis advised fathers not to marry a minor daughter, because she might not want to live with the man when she reached maturity. ${ }^{162}$ They exempted a woman who sold herself in perpetual slavery (Deut 15:17) from having her ear pierced, because it would blemish her beauty, an essential attribute for a woman. ${ }^{163}$ The rabbis established cases in which the woman has the right to ask for a divorce which the Court must enforce, ${ }^{164}$ and counselled old levirs not to marry young widows. ${ }^{165}$ If the rabbis had had such an ingrained evil opinion of women, they would not have made rules for the women's benefit, at times even against

159 Avraham Grossman, He Should Rule over You? Medieval Jewish Sages on Women (Hebrew; Jerusalem: Zalman Shazar Center for Jewish History, 2011), at 52-53 draws our attention to Rashi, who in one example ignored in his commentary on Gen 2:22 the slanderous midrash from Gen. Rab. parsha 18:2, and quoted instead the midrash of b. Erub. 18b on the same verse that God built the woman like a granary, slim in her upper body and stocky in her lower part to be suited to bearing a child (both midrashim cited in Chapter 1, pp. 25 and 42-43).

16o I therefore disagree with Jacob Neusner's statement in Method and Meaning in Ancient Judaism (Missoula, мт: Scholars Press, 1979) 79-100 at 97: "they [the framers of the mishnah] viewed them [the women] as abnormal, anomalous, dangerous, dirty, and polluting."

161 See supporting citations in Chapter 3, p. 125.

162 See $m$. Qidd. 2:1 and b. Qidd. 41a.

163 See b. Qidd. $17 \mathrm{~b}$.

164 M. Ket. 7:10 indicates a list of the husband's defects for which he is compelled [by the Court] to divorce his wife.

165 See Sifre Deut $15^{8 .}$ 
biblical ordinances. ${ }^{166}$ This endeavour demonstrates their intent to improve the legal status of women within the boundary of a woman's lacking the status of an independent legal entity. It makes much more sense to assume that their defamatory midrashim and some of their rules of separation between men and women had a practical purpose, and were not the result of a belief that women are wicked by nature. They did not, however, change women's dependent status, because it seemed to them, as I hypothesize, the natural consequence of the divine order of creation of woman from man to be his helper and part of him according to the Creation narrative, or else because they considered it unfeasible to enforce legal independence for women in the social environment of their period; as pragmatists they attempted to minimize some of dependency's hurtful consequences. The second possibility seems to me the more plausible, being in line with a pivotal element of their halakhic philosophy: "One does not promulgate a decree that the majority of the public cannot sustain" (b. B. Bat. 6ob).

\subsection{Conclusion, Part 1: Interpretations of the Creation and Fall Narratives}

The first part of this book has been dedicated to the biblical narratives of Creation and of the Fall and to the various interpretations, deductions, and consequences associated with them. We began with an unbiased interpretation of the relevant biblical texts. To better comprehend the many aspects and nuances of the narratives, the story was broken into its component segments and each verse, or at times each of its sections, was separately analysed. In the course of this process of interpretation and deduction, I cited scholarly opinions which agreed in part or entirely with my perceptions, and others which I disputed by means of contrary arguments. Due to the complexity of the narratives and their ramifications, a number of rabbinic and qumranic assertions were quoted in the frame of this interpretation in order to clarify the different viewpoints. I then cited qumranic and rabbinic texts relating directly to the biblical narratives, and others which seemed relevant for the apprehension of Qumran scholars' and rabbis' conceptions about women. I believe that both Qumran and the rabbis, and presumably their forerunners

166 For example, the woman's right to demand a divorce or the girl's prerogative not to marry the master to whom her father sold her. Hauptman, "Feminist Perspectives," at 49 writes about the innovative rabbinic rules for the benefit of women: "within the patriarchy, there seems to be a growing sympathy for women who are treated unfairly." 
the Pharisees, derived the attitudes towards women apparent in their writings from their distinct interpretations of the identical biblical texts, the basis of their general philosophy and theology. Each group, however, approached their analysis with different preconceptions, and thus arrived at different interpretive systems, which became evident in their distinct orientations, perspectives, and halakhot.

My interpretation of the biblical narratives led me to conclude that the scriptural attitude towards women, as transpires from the Creation and Fall narratives and subsequent scriptural assertions and rules, should be perceived as a two-pronged issue: on the one hand the legal status of women, and on the other their social standing in the family and community. Women's legal status, or rather their lack of it as individual legal entities, is the logical consequent of woman's creation from man, thus becoming once more a part of him at marriage, and of the purpose of her creation as man's helper, which forms the basis for her functional subordination to him. This lack of independent legal status is the foundation of the biblical laws regulating the woman's rights and obligations. ${ }^{167}$

Although women's lot according to scriptural regulations seems to us today pitifully underprivileged, it is representative of the dominant social customs and ordinances in the surrounding nations. While it is not my intention to justify such rules, I believe that in a research study of this nature, one bears the prevailing circumstances in mind. However, as I understand and have interpreted the biblical narratives, the first woman is not accused in Scripture of having initiated the expulsion from the Garden or of having provoked it by her seductive nature, enticing Adam to transgress the divine prohibition, this being conventionally seen in early Christian and rabbinic writings as the cause of death's advent and the other calamities befalling humanity. A close critical scrutiny of the biblical Fall narrative dispels this conventional interpretation, which blames the woman as primarily responsible for humanity's misfortunes. ${ }^{168}$

167 Sara Japhet, "The Expulsion of the Foreign Women (Ezra 9-10): The legal basis, and consequences for the definition of Jewish identity," in Sieben Augen auf einem Stein (Sach 3,9) Studien zur Literatur des Zweiten Tempels; Festschrift für Ina Willi-Plein zum 65. Geburtstag. (eds. Friedhelm Hartenstein and Michael Pietsch; Neukirchen-Vluyn: Neukirchener Verlag, 2007) 141-161, at 145 points out that "although Hagar is Sarah's maid, Sarah does not have the authority to act; this power resides exclusively with Abraham, the head of the family."

168 Levinson in The Right Chorale at 40 writes: "The story of the fall, like a poem by Wallace Stevens, is about how to read. Read correctly, the narrative challenges seduction." He further writes at 42 that biblical hermeneutics "demands an active interpreter to enter into thoughtful engagement with the text." 
Consistently with this finding, Scripture as a whole, when interpreted straightforwardly, does not yield any slanderous portrayals of women or allegations of their wicked character; on the contrary, we notice a host of commands to defend widows in various circumstances, to ensure their economic sustenance, and to share the joyful holiday meals with them (Deut 16:14). Exod 21:10 decrees the husband's obligations towards his wife.

Derogatory allegations against women are absent from Qumran literature, just as they are from Scripture. We may infer that the Qumran scholars' method of plain interpretation of the biblical texts led them to a conclusion about the principal responsibility for the Fall in broad concord with my suggested interpretation that Scripture does not implicate Eve as the primary mover of the sinful event. Thus, there is no reason from this perspective to denounce woman as having an inherently wicked, immoral character or to stigmatize her as dangerous and therefore to prevent men from sinning by avoiding any contact with women. Qumran held men responsible for their moral behaviour, accusing only men of sexual misdemeanour; women are not mentioned in their harsh criticism of sexual mischief and are not suspected of provoking it. Therefore, we observe in Qumran writings that women are taught the laws relevant for them $\left(\mathrm{Q}_{2} 8^{\mathrm{a}}\left({ }_{1} \mathrm{QS}^{\mathrm{a}}\right)\right.$ I:4-4-5) and partake in social events together with men (4Q502 (4Qpap Ritual of Marriage)).

These two corpora attend to the legal status of women both explicitly in their statutory writings and implicitly in their narrative writings. A woman did not hold an individual legal entity, except under the circumstance of widowhood or divorce; ${ }^{169}$ she was dependent in her youth on her father and after marriage on her husband, and that status constitutes the benchmark for the establishment of the legal rules regarding civil and ritual matters. Though we do not possess explicit regulations about all particular aspects of such matters, either in Scripture or in Qumran literature, we can assume that the basic criterion of woman's dependent legal status guided their various ramifications. Thus, for example, women were not obligated to perform all the biblical precepts, and according to Qumran rule were not permitted to participate in the Passover meal since they were not commanded to do so; nor were they members of the $E d a$, the holy group of mature males, but they were nevertheless respected members of the Jewish people and of the Qumran community, like youngsters of less than twenty years of age. Women's exclusion from the Eda is not on account of their defects or inferiority, but because Scripture commands it.

169 The father's authority over his minor daughter is permanently invalidated at her wedding, even if she is still a minor after her divorce or widowhood (m. Ket. 4:2 and b. Qidd. 18b). 
Qumran, like the rabbis, did not leave behind systematic interpretive comments on the biblical texts of the Creation and Fall narratives as the later traditional commentators did, and we can only infer their probable interpretation of the biblical texts and their underlying philosophy/theology from their writings. Whilst Qumran writings contain sparse treatises on the topic of women, the rabbinic literature by contrast is brimful with regulations about women and midrashim about their character and social functions; comprehension of rabbinic ideology and objectives is, therefore, much facilitated, as well as more secure in its conclusions.

The rabbis, in contrast to Qumran, demonstrate a composite image in their attitude towards women. They demonstrate in their halakhic literature a similar attitude to Qumran regarding the woman's lack of individual independent legal status and her dependence on the dominant male in her family, whether her father (while a minor) ${ }^{170}$ or her husband. ${ }^{171}$ However, the rabbis created a great array of detailed regulations through their midrashic system, complementing and expanding on the concise rules of Scripture. Some are precisely concordant with women's legal status as derived from a simple interpretation of scriptural commands and narratives, while others consist of halakhic innovations deduced by their midrashic system. The rabbis did not attempt to change women's dependent legal status, but attempted to set some rules for the practical improvement of women's adverse conditions resulting from this state of affairs.

Similar circumstances are manifest in rabbinic writings about women's character and social standing. Rabbinic midrashim and pronouncements about women range from outright slander concerning the first woman's actions and responsibility for the Fall, and consequently women's inherently wicked character, to exaltation for their indispensable social function in the family. The midrashic system allowed the rabbis to interpret the biblical Fall narrative, among others, in such a way as to indict the woman as the primary guilty party in Adam's defiance of the divine command, through her seductive influence on him.

The rabbis' negative opinion of women's character may have been influenced by the Hellenistic viewpoint, but I believe that as pragmatists they concluded that attributing to the woman a seductive trait (an attribute missing in

170 According to explicit rabbinic halakhah, and plausibly also by Qumran. See extended study about it in Chapter 3 .

171 Theodore Friedman, "The Shifting Role of Women, From the Bible to Talmud," Judaism, $36 / 4$ (1987) $479-87$, at 479 states that regarding the legal status of women "there is an obvious continuity between the Biblical and the Talmudic era." 
Scripture), thus portraying her as a dangerous entity, was justified as a powerful tactic in their attempts to avoid sexual misdemeanour in Jewish societyparticularly in view of her being easy prey for the libidinous menfolk due to her docile character. This thinking served as the foundation for the many regulations and exhortations prompting men to be vigilant in the face of female temptation, such as, for example, the maxim that it is safer to walk behind a lion than behind a woman. Stressing the danger of relationships with women, the rabbis enacted ordinances to avoid their company in various circumstances. In contrast to Qumran, the rabbis shifted the entire onus of ensuring a moral society onto the woman, establishing obligations upon women to wear decent and modest garments and to cover their hair, as well as a strict physical division between men and women in public locations. The purpose of these rules was the attempt to avoid sexual arousal in men through visual or physical contact with natural female beauty. Paradoxically, their apprehensions and rules do not indicate an attempt to forestall the "tempting women" from trying to seduce men for their pleasure, as one would expect for women with seductive tendencies. It seems that the rabbis did not perceive such a contingency as in any way likely, since they saw women as modest, as they acknowledged: "the woman does not make overture to the man" (cited in Gen. Rab. 17:8; see p. 98). Rather, they perceived a lack of male self-restraint, and therefore pragmatically devised ways of hiding women's physical attractiveness from them.

On the other hand, the rabbis placed great emphasis on harmonious family life, and guided again by their pragmatism understood that vilifying women would seriously impede the promotion of this goal. Consequently, to balance their "unflattering" attitude towards women's character, they created midrashim lauding women's positive qualities and emphasizing their crucial function within the family of ensuring a good life in all its aspects. This brings to mind a Yiddish folk aphorism: "it is not so good with them [the women] as it is bad without them." The midrashic system thus enabled the rabbis to interpret Scripture in line with their broad objective of ensuring the fulfillment of its rules, in ways they understood as being appropriate and effective in their contemporary circumstances. 